\title{
2010
}

Working Paper

(1)

INSTITUTO DE POLÍTIGAS Y BIENES PÚBLIGOS [IPP]

\section{THE CONTROL AND GENERATION OF TECHNOLOGY IN EUROPEAN FOOD AND BEVERAGE MULTINATIONALS}

\author{
Catalina Martínez \\ CSIC - Institute of Public Goods And Policies (IPP)
}

RUTH RAMA

CSIC - INSTITUTE OF ECONOMICS, GEOGRAPHY AND DEMOGRAPHY (IEGD) 


\section{INSTITUTO DE POLÍTICAS Y BIENES PÚBLICOS, CCHS-CSIC}

Copyright (C2010. Martínez, C. \& Rama, R.. All Rights reserved.

Do not quote or cite without permission from the author.

Instituto de Políticas y Bienes Públicos

Centro de Ciencias Humanas y Sociales

Consejo Superior de Investigaciones Científicas

C/ Albasanz, 26-28.

28037 Madrid (España)

Tel: +34 916022300

Fax: +34 913045710

http://www.ipp.csic.es/

The working papers are produced by Spanish National Research Council - Institute of Public Goods and Policies and are to be circulated for discussion purposes only. Their contents should be considered to be preliminary. The papers are expected to be published in due course, in a revised form and should not be quoted without the authors' permission.

\section{How to quote or cite this document:}

Martínez, C. \& Rama, R. (2010). The control and generation of technology in European food and beverage multinationals. Instituto de Políticas y Bienes Públicos (IPP), CCHS-CSIC, Working Paper, Number 6. Available: http://hdl.handle.net/10261/24409 


\title{
THE CONTROL AND GENERATION OF TECHNOLOGY IN EUROPEAN FOOD AND BEVERAGE MULTINATIONALS
}

\author{
Catalina Martínez \\ CSIC - Institute of Public Goods and Policies (IPP-CCHS); \\ CATALINA.MARTINEZ@CCHS.CSIC.ES
}

RUTH RAMA

CSIC - INSTITUTE OF ECONOMICS, GEOGRAPHY AND DEMOGRAPHY (IEGD-CCHS); RUTH.RAMA@CCHS.CSIC.ES

\begin{abstract}
Using a sample of 59 major European food and beverage multinationals and their 8,432 subsidiaries worldwide, we study the characteristics and evolution over time of their inventions. In doing so, we analyse: i) 8,626 EPO applications filed by these companies between 1978 and 2005; ii) 3,650 US patents they applied for between 1978 and 2001; iii) more than 2,000 patent families of three different kinds; and iv) the location of their R\&D entres of excellence. We find that the internationalisation of invention is in reality chiefly a European phenomenon for these companies, which also tend to retain their key R\&D strategic assets within their home countries or in neighbouring countries. The innovations of EU-based companies which are most closely related to their core businesses tend to be located in EU countries; however, such companies do not display a geographical preference with regard to high value or technically complex innovations, which are generated at home and abroad and inside and outside the EU. From these findings we extract conclusions relevant to European R\&D policy.
\end{abstract}

Key words: Food and beverage multinationals; innovation; patents; R\&D; globalisation JEL classification: F23; O32 


\section{CONTENTS}

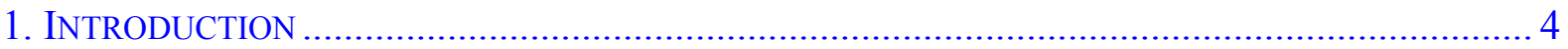

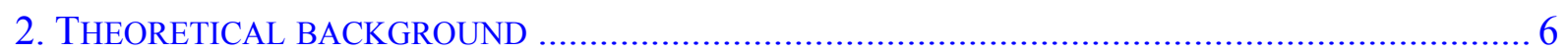

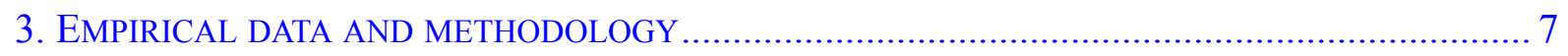

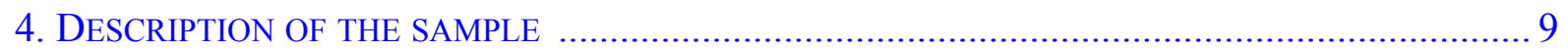

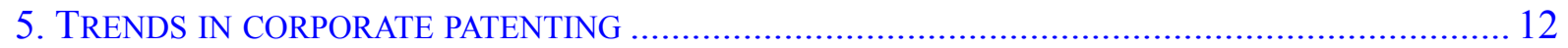

6. THE GEOGRAPHICAL DISTRIBUTION OF PATENTING ACTIVITIES........................................... 16

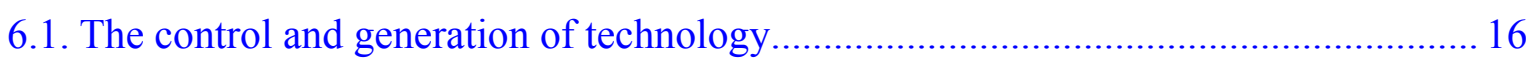

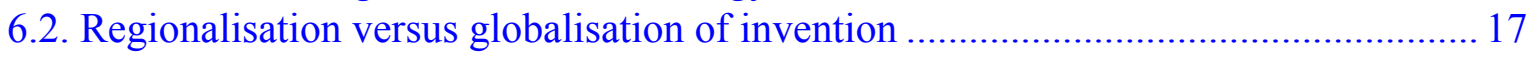

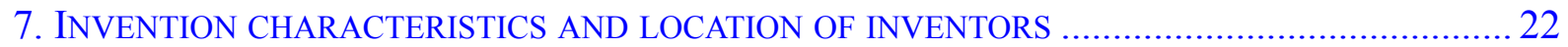

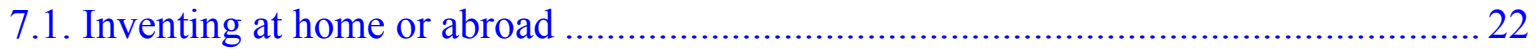

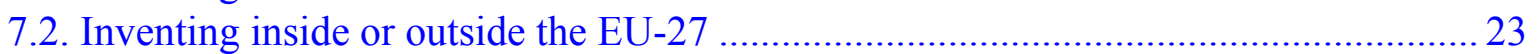

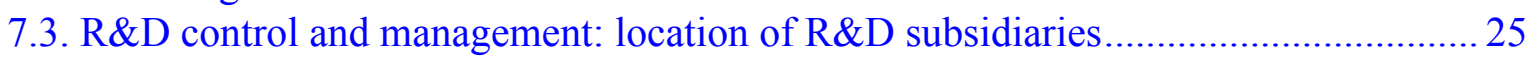

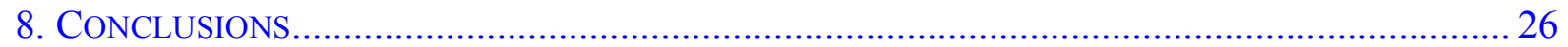

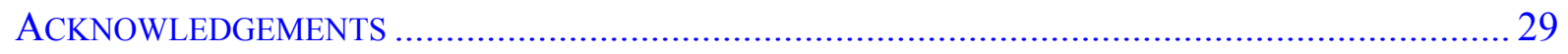

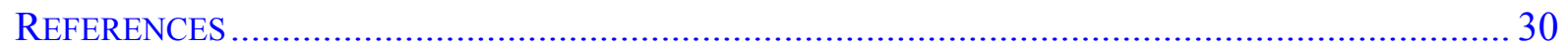

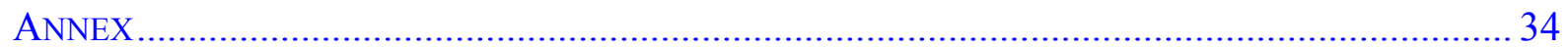




\section{INTRODUCTION}

Multinational enterprises (MNEs) innovate abroad, among other reasons, to adapt their products to host country tastes, absorb new knowledge from world centres of excellence or benefit from low-cost, good-quality local R\&D. ${ }^{1}$ Despite the internationalisation of R\&D activities having become increasingly common (UNCTAD 2005), it remains unclear whether this is desirable either for MNEs' home countries or for host countries. The relocation of indigenous firms' $R \& D$ centres may restrict technological opportunities in the domestic market (Archibugi and Iammarino 1999), and may also involve a loss of technological capabilities for the home country or, at least, signal that the home country is insufficiently attractive to innovative MNEs (Doz 2005; Sachwald 2005). One reason for the controversy surrounding the internationalisation of R\&D may be that the empirical evidence available is still insufficient (Dunning and Narula 1996; Dunning 1994; Serapio, Takabumi and Dalton 2004); in some cases, information is nonexistent or confined only to high-tech sectors.

However, MNEs appear to differ in their propensity to engage in R\&D activities abroad, depending on the sector in which they operate (Cantwell and Janne 2000; Patel and Pavitt 1991); consequently, studies of the so-called mature sectors, such as food and beverages, are required. Apparently, food and beverage multinationals (hereafter F\&B MNEs) are especially inclined to undertake their R\&D activities abroad (Alfranca, Rama and von Tunzelmann 2005; Cantwell and Hodson 1991; Patel 1995), probably because of the need to adapt their products to different national tastes and food safety regulations. The globalisation of industrial R\&D in this sector has been a cause for concern, especially in European countries which depend heavily on agro-industrial production and exports (Bijman, van Tulder and van Vliet 1997). Since European companies play an important role worldwide in innovations employed by the food and drink sector and auxiliary industries (Christensen, Rama and von Tunzelmann 1996; von Tunzelmann 1998), it is interesting to assess whether Europe is attractive to indigenous F\&B MNEs.

$1 \quad$ Blanc, H., and C. Sierra. (1999). 'The internationalisation of R\&D by multinationals: a trade-off between external and internal proximity’. Cambridge Journal of Economics (23),187-206, Cantwell, J., and S. Iammarino. (2000). 'Multinational corporations and the location of technological innovation in the UK regions'. Regional Studies (34),317-332, Cantwell, J., and O. Janne. (1999). 'Technological globalization and innovative centres: the role of corporate technological leadership and locational hierarchy'. Research Policy (28),119-144, Cantwell, J., and E. Kosmopoulou. (2001). 'Determinants of internationalisation of corporate technology.' Pp. 35 in DRUID Working Papers, Cantwell, J., and L. Piscitello. (1999). 'The emergence of Corporate International Networks for the accumulation of dispersed technological competences'. MIR 123-147, Cantwell, J., and G. D. Santangelo. (1999). 'The frontier of international technology networks: sourcing abroad the most highly tacit capabilities'. Information Economics and Policy (11),101-123, Meyer-Krahmer, V.F., and G. Reger. (1999). 'New perspectives on the innovation strategies of multinational enterprises: lessons for technology policy in Europe'. Research Policy (28),751-776, Pearce, R. (1999). 'Decentralised R\&D and strategic competitiveness: globalised approaches to generation and use of technology in multinational enterprises (MNEs)'. Research Policy (28),157-178, Pearce, R., and M. Papanastassiou. (1999). 'Overseas R\&D and the strategic evolution of MNEs: evidence from laboratories in the UK'. Research Policy (28),23-41, Reddy, P. (1993). 'Emerging patterns of internationalization of corporate R\&D: opportunities for developing countries?’ Pp. 78-101 in, C. Brundenius and G. Göransson (ed). New technologies and global restructuring. The Third World at a crossroads. L.A.: Taylor Graham.. 
In spite of the importance of the food and drink industry within the EU-27 manufacturing sector, our empirical knowledge of the dimensions and characteristics of R\&D globalisation in this industry remains limited. Previous studies suggest that, compared to other European MNEs, their F\&B counterparts tend to patent a substantial proportion of their innovations outside Europe, notably in the USA (Cantwell and Janne 2000). Most such research, however, has concentrated on patents granted by the US Patent and Trademark Office (USPTO), especially in the 1980s and 1990s. Other cross-sectional studies which include the food industry have been based exclusively upon applications made to the European Patent Office (EPO) (Abramovsky et al 2008).

The shortcomings of the information available make it difficult to ascertain whether the national (or regional) $\mathrm{R} \& \mathrm{D}$ intensity of European $\mathrm{F} \& \mathrm{~B}$ MNEs is being negatively affected by foreign $\mathrm{R} \& \mathrm{D}$, as some have feared. To date, no comparative temporal analysis has been performed of inventions produced inside and outside Europe, and inside and outside EU companies' home countries, by combining the data (held by the EPO and the USPTO) for applicants' and inventors' locations, as this study does. There is a need to complement previous research work by using contrasting sources of information (EPO and USPTO) and varied approaches to R\&D internationalisation.

The present paper studies the internationalisation of R\&D for 59 major European F\&B MNEs, which have a total of 8,432 subsidiaries. We examine where such firms are locating their R\&D activities worldwide, by studying the locations of: i) the patent applicant; ii) the inventor and iii) companies' R\&D centres of excellence. In doing so, we analyse the 8,626 EPO applications filed by these firms in 1978-2005, the 3,650 USPTO patents they applied for in 1978-2001 and the location of their R\&D subsidiaries. To complement the analysis of the location of inventors, we also employ data for patent families of three different types, the earliest priority years of which were between 1978 and 2000: 2,662 triadic, 5,993 international and 2,462 PCT patent families. We consider a relatively long time period for all these patent indicators, to ensure that we capture as many innovations as possible in the mature and conservative food and beverage industry, where consumers' tastes tend to change slowly (Galizzi and Venturini 2008).

It has been claimed (although not yet proven) that the new knowledge which European agrofood firms require is currently underdeveloped in Europe, as National Systems of Innovation (hereafter NSIs) are unable to supply such companies with adequate information and support; NSIs may be evolving more slowly than corporate technological requirements (Narula 2000). However, very little is known about the types of innovations developed at home and abroad, whether in Europe or further afield, and an analysis of their differences may help us to understand why European F\&B MNEs innovate abroad. An understanding of whether the nature of corporate innovation is different at home and abroad (the EU-27 and elsewhere) is important for home country governments, due to the macroeconomic and sectoral effects generated by the largest indigenous F\&B MNEs. 
The present article aims to contribute to the empirical literature on the internationalisation of R\&D. We will argue that European F\&B MNEs are regionalising rather than internationalising their R\&D activities. The paper also investigates whether such firms develop similar types of R\&D activities at home and abroad, in Europe and elsewhere.

The paper is organised as follows. The following section recounts the theoretical background. Section 3 describes the empirical data and methodology employed, while Section 4 presents the main characteristics of the F\&B MNEs analysed in the study. Section 5 examines their corporate patenting trends, Section 6 the geographical distribution of their patenting activities and Section 7 tests the hypothesis that companies may perform different types of R\&D activities at home and abroad and inside and outside Europe. Section 8 offers our conclusions.

\section{THEORETICAL BACKGROUND}

Some authors, defined by Archibugi and Iammarino (1999) as the "sceptics of globalisation", maintained in the 1990s that many MNEs have little interest in internationalising their R\&D activities because they prefer to innovate in their home countries (Patel and Pavitt 1991; Patel and Vega 1999; Patel and Pavitt 1995; Patel and Pavitt 1997). Furthermore, a recent review of the literature on the internationalisation of corporate R\&D suggests that much of the innovative activity of MNEs continues to take place at home (Dunning and Lundan 2009).

As stated earlier, F\&B MNEs seem especially inclined to internationalise their R\&D activities, a phenomenon often explained by corporate needs to adapt products to national tastes and safety regulations (Alfranca, Rama and von Tunzelmann 2005). Cantwell and Hodson (1991) observe that by the mid-1980s $24.0 \%$ of the patents granted in the United States (hereafter US) to the world's largest food and drink companies were attributable to research performed abroad rather than in the home country. Patel (1995) notes that by the beginning of the 1990s the world's largest food multinationals patented abroad $26.3 \%$ of their innovations, while the equivalent figure for large drink and tobacco multinationals was 30.7\%. According to other studies, the largest European F\&B MNEs patent abroad $83.4 \%$ of their total inventions, while the largest US F\&B MNEs patent abroad only $10.0 \%$ of their total inventions (Alfranca, Rama and von Tunzelmann 2005; Cantwell and Janne 2000). Since most analyses to date have been based on the number of patents granted by the USPTO, one of the objectives of this paper is to verify whether the apparent importance of $R \& D$ internationalisation in such European firms is confirmed when we employ: i) multiple data sources (e.g. USPTO and EPO) instead of a single source and ii) location indicators for all the applicants (or assignees) and all the inventors listed in patent documents. ${ }^{2}$

It has been argued that the internationalisation of $\mathrm{R} \& \mathrm{D}$ is in fact largely a regional process,

$2 \quad$ For the sake of simplicity we will use the term "applicants" throughout the paper to refer to both patent applicants and patent assignees (the owners of USPTO patent grants). 
principally involving European MNEs which innovate in other European countries (Archibugi and Michie 1995), and the present paper maintains that the internationalisation of R\&D for European F\&B MNEs is indeed chiefly a European phenomenon. According to some authors, corporations do not perform the same type of R\&D at home and abroad. MNEs tend today to use their foreign subsidiaries to generate genuine innovation in addition to adapting their products to national markets (Edler 2008), although it has been claimed that such companies nevertheless continue to retain their most important R\&D activities close to their headquarters (Cohen et al. 2009; Hu 1992; Narula 2000). In a study of the telecom and automobile industries, Cohen et al (2009) distinguish important $R \& D$ from routine $R \& D$ and demonstrate that the former, more complex and costly, tends to be performed in companies' home countries. We maintain that F\&B MNEs tend to perform at home (or, at least, in regional locations, namely within the EU27) those $R \& D$ activities they believe to be more complex, expensive and strategic i.e. most closely related to their core business.

MNEs may risk losing technological coherence by dividing their innovative activities among dispersed localities (Blanc and Sierra 1999). Companies solve this problem by, among other methods, launching subsidiaries which specialise in research-related activities and can coordinate and direct innovation within the multinational network (Gassmann and von Zedtwitz 1998; Gerybadze and Reger 1999; von Zedtwitz, Gassmann and Boutellier 2004). Although this type of R\&D organisation appears to have been originally implemented by MNEs operating in hightech sectors, it is also currently being adopted by F\&B MNEs, especially when these are highly internationalised or innovative (Filippaios et al. 2009).

These specialised subsidiaries are not necessarily located in the home country. Nevertheless, according to Cohen et al (2009), traditional centres of research located in the home country enjoy accumulated expertise and reputation, while foreign $R \& D$ subsidiaries have a long learning curve. The present paper tests whether the R\&D subsidiaries of the companies sampled are located within Europe (either in the home country or in other European countries) or further afield. We argue that European F\&B MNEs tend to retain in Europe those tasks involving the coordination and management of global R\&D.

Data regarding the internationalisation of $R \& D$ are not fully comparable and research methods vary between studies (OECD 2005), restricting the possibility of comparing different authors' results and requiring this phenomenon to be approached from various angles and a variety of indicators to be employed. We turn to this question in the following section.

\section{EMPIRICAL DATA AND METHODOLOGY}

The companies analysed in the present study are European-based multinationals included in the worldwide ranking of agro-food multinationals in the AGRODATA database, compiled by the Institut Agronomique Méditérrannéen de Montpellier (France). We combined information from 
this source and from other databases on corporate information and patents to obtain a global picture of their facilities and patenting activities.

Firstly, we identified all the subsidiaries of the selected F\&B MNEs and extracted information regarding their names, locations and principal industrial sectors of activity from the Bureau van Dijk (BvD) AMADEUS database, version March 2008³. Secondly, we matched patent counts to the company names corresponding to the F\&B MNEs selected. We are aware that mergers and acquisitions and the closure of subsidiaries prior to the compilation of the information on subsidiaries may alter patent counts but, following Criscuolo et al (2002), we feel this methodology is acceptable for our purposes, since most multinationals apply for the majority of their patents using variations of their corporate name. R\&D subsidiaries are defined as those having NACE 1.1 class 7310 (i.e. "research and experimental development on natural sciences and engineering") as their main or secondary sector of activity.

Empirical studies often measure the innovative performance of firms using patent data. Although there are drawbacks associated with such information, the advantages of its availability and richness are widely recognised (Griliches 1990). To date, most studies of R\&D and patent globalisation have relied on single patent indicators, and most often USPTO patent grants (e.g. Patel and Vega, 1999; Belderbos, 2001; Alfranca et al, 2004; Filippaios et al. 2009). Exceptions are the multi-sectoral studies by Le Bas and Sierra (2002) and Quintás et al. (2008), using EPO applications; the study by Rama (1999) of the agro-food sector, based on patents granted by the Spanish Patent and Trademark Office; and the work by Cohen et al. (2009), employing essential patents for wireless telecom standards notified to the European Telecommunications Standards Institute (ETSI).

Those in favour of utilising USPTO patent data have traditionally argued that US patents, as they eliminate home bias, are probably the best "foreign patent indicator" available, given the importance of the US market. Le Bas and Sierra (2002), employing data on EPO patent applications instead, insist on their advantages over US patent grant information. For example, the EPO is an international patent office (a one-stop shop for applicants wanting to gain protection in all or some of the contracting states of the European Patent Convention), rather than a national office granting domestic rights like the USPTO. Furthermore, the two bodies have different disclosure rules (until 2001 the USPTO only published patent grants, whereas the EPO has always published pre-grant applications). ${ }^{4}$ Other authors have signalled that pending patent applications (i.e. finally granted or not) are more appropriate as proxies of the inventive activity of firms, since such counts are not affected by patent office procedures (Basberg 1987; Dernis and Khan 2004). ${ }^{5}$ We agree with these views and prefer to measure

3 Some of the information used by BvD analysts to complete the ownership data included in the March 2008 version of Amadeus dates from 2004.

4 The European Patent Organisation had 36 member countries in 2009, including EU countries, but also non-EU members such as Switzerland, Norway and Turkey. For a complete list, see http://www.epo.org/about-us/ epo/member-states.html

5 Basberg (1987) notes that "the advantage of using data for applications pending, instead of the actual 
invention by applications (either based on applications to single patent offices, such as the EPO, or consolidating applications to different offices in patent families), but also perform comparisons with USPTO data on patent grants, to compare our results with previous studies.

We extract information from the September 2008 EPO Worldwide Patent Statistics Database (PATSTAT) on USPTO patent grants, EPO applications and three types of patent families filed by the F\&B MNEs sampled; we obtain from Amadeus the names of all their subsidiaries and corresponding host countries and match them with the names and countries of residence of EPO applicants and USPTO assignees. ${ }^{6}$ The OECD Patent Statistics Manual (2009) defines patent families as "the set of patents (or applications) filed in several countries which are related to each other by one or several common priority filings". From among the variety of patent family definitions to be found in the literature (Martínez 2010), we have chosen, firstly, triadic patent families (comprising patents filed in the three major patent offices worldwide, namely the EPO, USPTO and the Japan Patent Office (JPO) ${ }^{7}$; secondly, international patent families (sets of patents protecting identical or closely related inventions and filed in at least two different patent offices); and thirdly, PCT patent families (sets of patents protecting the same or closely related inventions that involve at least one PCT application). Table A1 in the Annex presents a ranking of the sampled F\&B MNEs on the basis of the five patent indicators considered.

\section{DESCRIPTION OF THE SAMPLE}

Our sample comprises 8,432 subsidiaries of 59 major European F\&B MNEs. Their parent companies are based in 11 EU-27 countries and Switzerland. Table 1 shows the most important home countries in terms of their share of both the number of F\&B MNEs and the number of their subsidiaries.

The most important location for the subsidiaries examined is the UK, which accounts for approximately $27 \%$ of both domestic and foreign subsidiaries. The most important host countries are the UK and the US; the data include, in this case, only the foreign subsidiaries of the F\&B MNEs sampled. These considerations are important, because corporate R\&D tends to follow, with a time lag, foreign direct investment (FDI) (Blanc and Sierra 1999). In the F\&B industry, moreover, a substantial proportion of innovation consists of small improvements

number of patents granted, is that they reflect the inventor's interest in obtaining protection and also the importance which the inventor holds in the system". Furthermore, Dernis and Khan (2004) argue that "measuring innovative performance using the grants data will provide a partial picture as it will discard the innovative effort of the unsuccessful patents."

6 We do this by first applying a cleaning and matching algorithm to create an initial selection of possible positive matches between company names from Amadeus and applicant names from PATSTAT; we then manually validate these, based on additional information from Amadeus and other sources, such as company websites.

$7 \quad$ Inclusion within a triadic patent family has been shown to be an indicator of high patent value (Grupp et al., 1996; Grupp, 1998; Dernis, Guellec and van Pottelsberghe, 2001; Dernis and Khan and 2004; Guellec and van Pottelsberghe, 2004). The other two types of families are more inclusive and aim to capture lower-value patents for which applicants nevertheless seek some sort of international protection (e.g. in at least two different jurisdictions for international families, and using the PCT route for PCT patent families). 
and the adaptation of foodstuffs to national tastes (Galizzi and Venturini 2008); as a result, companies need to locate their laboratories close to their manufacturing facilities.

Table 1 also indicates the average size of companies, as measured by their global sales, food sales and number of employees in 2005 , in addition to average patent counts by company (measured by EPO applications filed in 1978-2005 and USPTO grants for patents filed in 19782001).

The largest companies, as measured by any of these indicators, are Nestlé and Unilever, although the sample is highly diverse with regard to financial data and the number of employees and patents, as Table 1 shows. Turning to patenting activities, 14\% of the sampled F\&B MNEs did not file any EPO applications in the period considered, while $37 \%$ filed over 25 applications. A similar situation is reflected by USPTO patent grants. Unilever, the most innovative company in our sample, filed 4,833 EPO applications in this period and was granted 2,244 USPTO patents. These findings confirm a previous study based on US patent grants to the world's largest F\&B MNEs (Alfranca, Rama and von Tunzelmann 2002), which concluded that a small nucleus of innovators directed innovation in this international industry and, moreover, that a considerable number of F\&B MNEs only patented sporadically or not at all in 1977-1994. Table A1 in the Annex identifies the most innovative companies in our sample; whichever patent proxy is employed, Unilever and Nestlé are the leaders. 
Table 1. Description of the sample

\begin{tabular}{|l|c|c|c|c|c|c|c|c|}
\hline $\begin{array}{l}\text { COMPANY SIZE } \\
\text { (Parent company information } \\
\text { for fiscal year 2005) }\end{array}$ & N & Min. & Max. & Median & Mean & Std dev. & $\begin{array}{c}\text { Trimmed } \\
\text { mean } \\
\mathbf{( 5 \% )}\end{array}$ & Sum \\
\hline Sales (in millions of euros) & 59 & 647 & 58,452 & 2,698 & $5,546.39$ & $9,058.86$ & $3,993.75$ & $327,236.76$ \\
\hline $\begin{array}{l}\text { Food sales (in millions of } \\
\text { euros) }\end{array}$ & 57 & 300 & 54,626 & 2,606 & $4,853.37$ & $7,809.42$ & $3,608.34$ & $276,642.13$ \\
\hline $\begin{array}{l}\text { Employment (number of } \\
\text { employees) }\end{array}$ & 59 & 1,487 & 250,000 & 10,516 & 23,793 & 43,131 & 16,025 & 1,403785 \\
\hline
\end{tabular}

\begin{tabular}{|c|c|c|c|c|c|c|c|c|c|}
\hline HOME COUNTRIES & \multicolumn{3}{|c|}{$\begin{array}{l}\text { \% of parent companies } \\
(\mathrm{N}=59)\end{array}$} & \multicolumn{3}{|c|}{$\begin{array}{l}\text { SUBSIDIARIES, BY MNE } \\
\text { HOME COUNTRY }\end{array}$} & \multicolumn{3}{|c|}{$\begin{array}{l}\text { \% total number of subsidiaries } \\
\qquad(\mathrm{N}=8432)\end{array}$} \\
\hline United Kingdom & \multicolumn{3}{|c|}{22.0} & \multicolumn{3}{|c|}{ France } & \multicolumn{3}{|c|}{21.8} \\
\hline France & \multicolumn{3}{|c|}{18.6} & \multicolumn{3}{|c|}{ United Kingdom } & \multicolumn{3}{|c|}{20.0} \\
\hline Netherlands & \multicolumn{3}{|c|}{13.6} & \multicolumn{3}{|c|}{ Netherlands } & \multicolumn{3}{|c|}{16.9} \\
\hline Germany & \multicolumn{3}{|c|}{8.5} & \multicolumn{3}{|c|}{ Ireland } & \multicolumn{3}{|c|}{10.7} \\
\hline Ireland & \multicolumn{3}{|c|}{8.5} & \multicolumn{3}{|c|}{ Switzerland } & \multicolumn{3}{|c|}{9.3} \\
\hline Italy & \multicolumn{3}{|c|}{8.5} & \multicolumn{3}{|c|}{ Denmark } & \multicolumn{3}{|c|}{8.2} \\
\hline Denmark & \multicolumn{3}{|c|}{6.8} & \multicolumn{3}{|c|}{ Germany } & \multicolumn{3}{|c|}{5.7} \\
\hline Switzerland & \multicolumn{3}{|c|}{5.1} & \multicolumn{3}{|c|}{ Spain } & & & \\
\hline Spain & & & & Italy & & & & & \\
\hline Belgium & & & & Bel & ium & & & & \\
\hline Finland & & & & Finl & & & & & \\
\hline Sweden & & & & Swe & den & & & & \\
\hline $\begin{array}{l}\text { LOCATION } \\
\text { (top } 20 \text { locations, } \\
\text { domestic and foreign) }\end{array}$ & $\begin{array}{r}\% \text { of total } \\
\text { domestic } \\
(\mathrm{N}=\end{array}$ & $\begin{array}{l}\text { ubsic } \\
\text { nd fo } \\
432 \\
\end{array}$ & $\begin{array}{l}\text { iaries, } \\
\text { reign }\end{array}$ & & $\begin{array}{l}\text { IOST COI } \\
\text { p } 20 \text { foreig }\end{array}$ & $\begin{array}{l}\text { NTRIES } \\
\text { locations) }\end{array}$ & & $\%$ of for & iaries \\
\hline United Kingdom & & .5 & & Uni & ed Kingdor & & & & \\
\hline France & & & & Uni & ed States & & & & \\
\hline Germany & & 3 & & Ger & nany & & & & \\
\hline Netherlands & & & & Fra1 & & & & & \\
\hline Ireland & & 1 & & $\mathrm{Net}$ & erlands & & & & \\
\hline United States & & & & Spa & & & & & \\
\hline Spain & & & & Irel: & & & & & \\
\hline Italy & & & & Chi & & & & & \\
\hline Denmark & & & & Polc & & & & & \\
\hline China & & & & Italy & & & & & \\
\hline Poland & & & & Bel & ium & & & & \\
\hline Belgium & & & & Aus & & & & & \\
\hline Switzerland & & & & Can & & & & & \\
\hline Austria & & & & Rus & ian Federat & & & & \\
\hline Canada & & & & $\mathrm{Bra}$ & & & & & \\
\hline Russian Federation & & & & $\mathrm{Mer}$ & & & & & \\
\hline Brazil & & & & Aus & ralia & & & & \\
\hline Mexico & & & & Swe & & & & & \\
\hline Sweden & & 9 & & Por & igal & & & & \\
\hline Australia & & 9 & & Sin & apore & & & & \\
\hline PATENT COUNTS & & $\mathbf{N}$ & Min. & Max. & Median & Mean & Std dev. & $\begin{array}{c}\text { Trimmed } \\
\text { mean } \\
(5 \%) \\
\end{array}$ & Sum \\
\hline $\begin{array}{l}\text { EPO patent applications } \\
1978-2005)\end{array}$ & years & 59 & 0 & 4,833 & 11 & 146.20 & 673.13 & 29.40 & 8,626 \\
\hline $\begin{array}{l}\text { USPTO patent grants (fil } \\
\text { 2001) }\end{array}$ & years 1978- & 59 & 0 & 2,244 & 4 & 61.86 & 301.31 & 12.35 & 3,650 \\
\hline
\end{tabular}

Sources: AGRODATA for corporate information, BvD AMADEUS for information on subsidiaries and PATSTAT for patent counts. 


\section{TRENDS IN CORPORATE PATENTING}

Both the total number of EPO patent applications filed by the largest European F\&B MNEs and the total number of USPTO patents granted to them rose significantly during the period analysed. Despite differences between the two data sources (EPO applications comprise both applications which have been granted and those which have not), Figure 1 is useful to show, by national group, the trends in corporate R\&D producing patentable inventions. Swiss and Dutch companies are the most innovative, while countries such as Finland and Spain display very low technological performance, accounting for less than $1 \%$ of the patent counts of the firms sampled (not displayed).

Figure 1. The most innovative companies, by home country

Figure 1a. EPO applications filed by European F\&B MNEs, by home country

Filing years 1978-2005

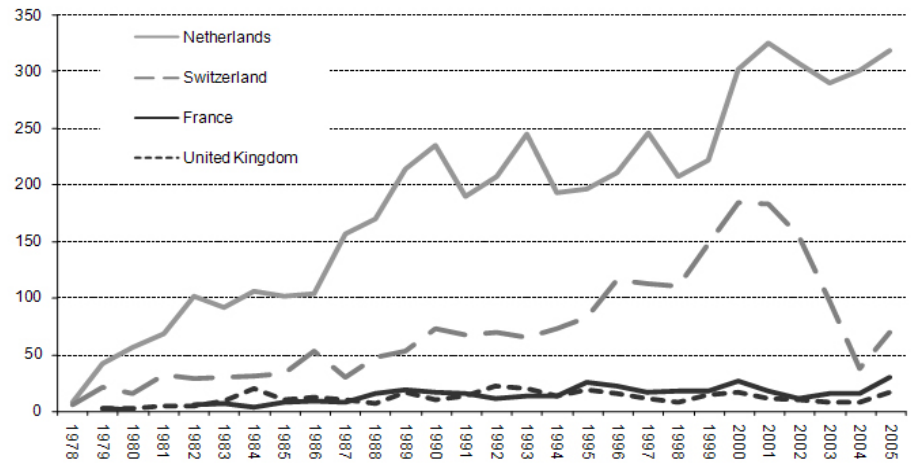

Figure 1b. USPTO patents granted to European F\&B MNEs, by home country Filing years 1978-2001

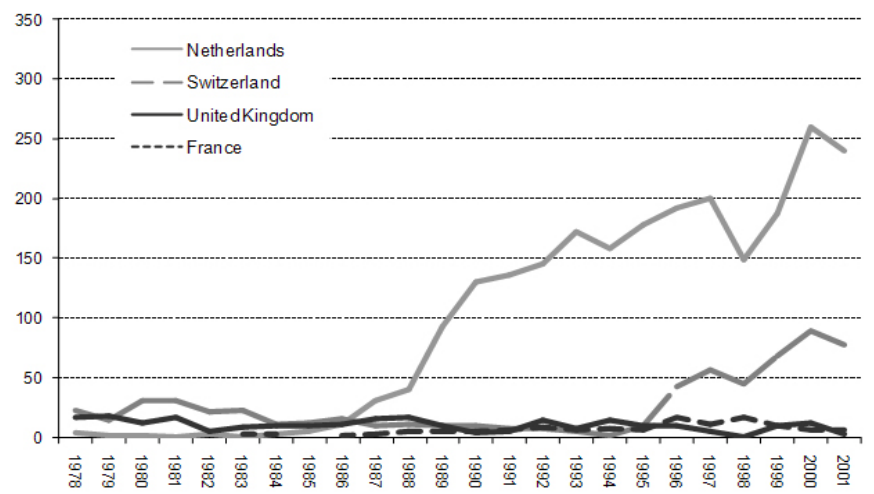

Note: Only the four home countries with the highest number of patents are represented in the graph Source: Own elaboration, based on patent data from PATSTAT September 2008 and information on subsidiaries from BvD Amadeus 2008 for a selection of Top European F\&B MNEs, taken from Agrodata 2005. 
We also investigate which technological fields have attracted most interest from European companies, considering seven broad technological areas. Between 1978 and 2005, the companies sampled filed 8,626 EPO applications, of which 3,128 were for the protection of food inventions and 5,498 for non-food inventions. Non-food applications thus accounted for $64 \%$ of total EPO applications, although their share has tended to fall, from $67 \%$ for the period $1978-1990$ to $63 \%$ in $1991-2005$. This result is coherent with previous studies which note the substantial share of non-food innovation produced by the world's largest F\&B MNEs (Alfranca, Rama and von Tunzelmann 2004; von Tunzelmann 1998). The USPTO granted the sampled companies 3,650 patents, of which 2,755 were non-food patents (75\%). Once more, the data show the importance of non-food innovation for European F\&B MNEs, but in contrast to information on EPO applications, the share of non-food US patents has increased over time, from $64 \%$ in $1978-1990$ to $79 \%$ in $1990-2001$.

F\&B MNEs innovate in non-food fields for two main reasons: firstly, some of them are conglomerates whichalso producenon-food items (e.g. Unilever); secondly, and more importantly, F\&B MNEs need to acquire expertise in the upstream technology used for food production. Since approaches to food quality and safety are becoming increasingly multidisciplinary (Christensen, Rama and von Tunzelmann 1996), non-food-based innovation may well help F\&B companies to interact better with their suppliers of technology (e.g. equipment suppliers). Consequently, even non-diversified F\&B MNEs (i.e. companies dedicated exclusively to food production) devote part of their innovative efforts to non-food innovation (Alfranca, Rama and von Tunzelmann 2003).

As Figure 2 shows, the majority of EPO applications filed by European F\&B MNEs in 19782005 fall within three fields: pharmaceuticals and biotechnology, chemicals, and industrial processes. Applications in the pharmaceuticals and biotechnology field, the most important for such companies, include both food (65\%) and non-food applications (35\%). In the case of USPTO patent grants, the field of pharmaceuticals-biotechnology produces most inventions, but in contrast to EPO applications non-food inventions are predominant, representing $56 \%$ of all pharma-biotech US patents granted to the F\&B MNEs sampled. With regard to their evolution over time, the share of non-food inventions in the field of pharma-biotech has increased both for EPO applications and USPTO patent grants, although the latter has experienced a sharper increase, from $29 \%$ in $1978-1990$ to $63 \%$ in 1991-2001. In turn, non-food applications rose from $31 \%$ of all EPO pharma-biotech applications filed in $1978-1990$ to $36 \%$ in $1990-2005){ }^{8}$

8 The breakdown of food and non-food patent counts within the pharmaceutical-biotechnology field is not displayed in the Figures. 
Figure 2. Patent counts by technological field

Figure 2a. EPO applications filed by European F\&B MNEs: food $v s$ non-food

Filing years 1978-2005

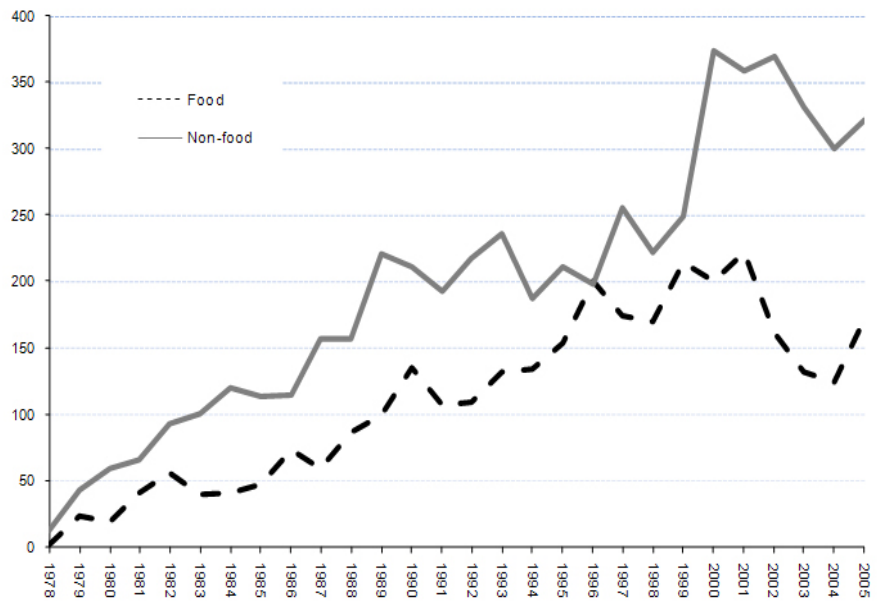

Figure 2b. EPO applications filed by European F\&B MNEs: principal technology fields Filing years 1978-2005

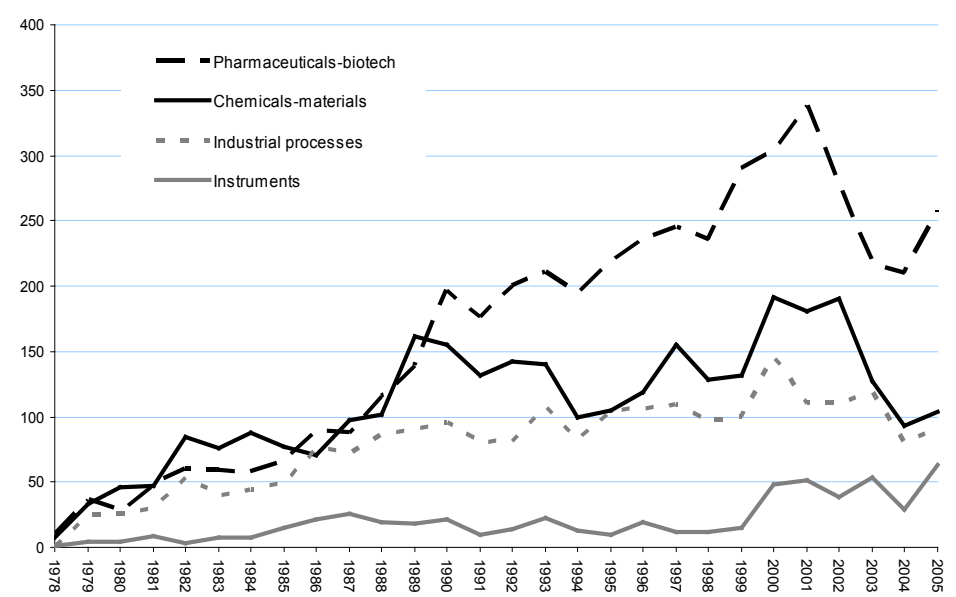


Figure 2c. USPTO patent grants filed by European F\&B MNEs:

food vs non-food

Filing years 1978-2001

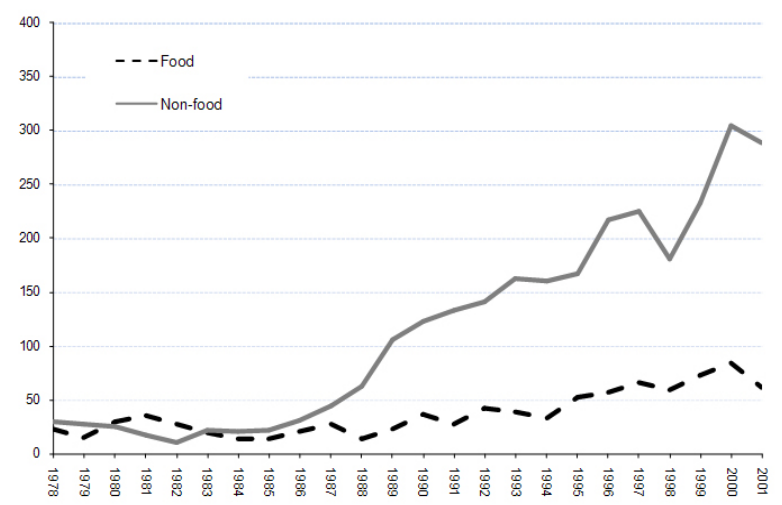

Figure 2d. USPTO patent grants filed by European F\&B MNEs: principal technology fields

Filing years 1978-2001

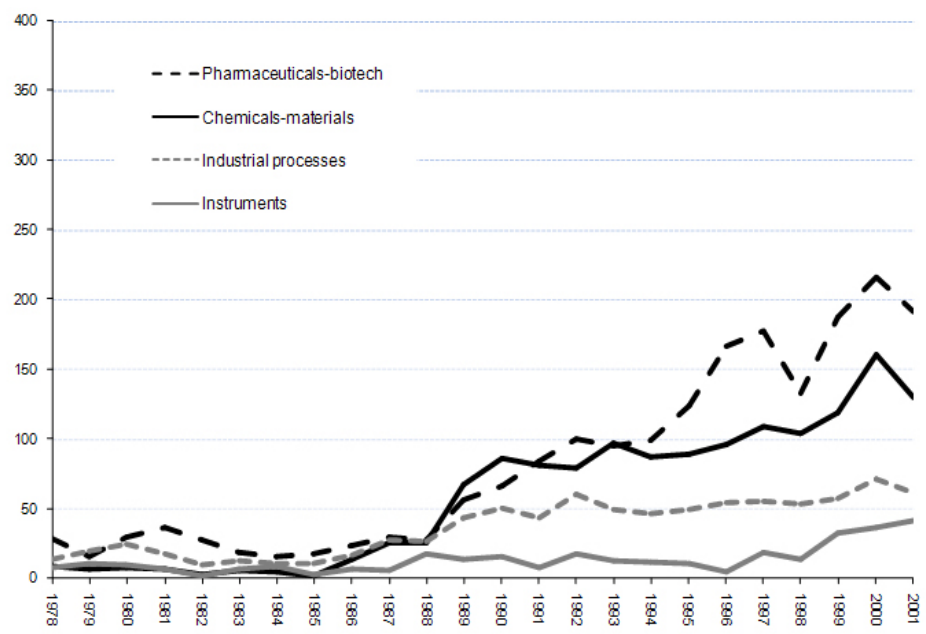

Notes: "Food": at least one IPC class belongs to the technology subfields "Food and Agriculture" or "Food and Agriculture Machines \& Tools"; "Non- Food": no IPC class belongs to the two subfields related to food.

The distribution of patents by technology field is based on full counting (as opposed to fractional counting), using the total number of patents filed by the MNE group (including all its domestic and foreign subsidiaries).

Source: Own elaboration, based on patent data from PATSTAT September 2008, information on subsidiaries from BvD Amadeus 2008 for a selection of Top European F\&B MNEs, taken from Agrodata 2005, and the 7 broad technology fields and 30 subfields contained in the second revision of the IPC correspondence OST-INPI/FhFISI." 


\section{THE GEOGRAPHICAL DISTRIBUTION OF PATENTING ACTIVITIES}

In this section we study the geographical distribution of the patenting activities of European F\&B MNEs. We analyse information provided by patent documents, such as the location of applicants and inventors, in order to establish what proportion of such activities is performed at home or abroad, and inside or outside the EU-27.

\subsection{The control and generation of technology}

Firstly, we analyse recent trends in the location of the inventors registered in EPO applications filed by the sampled companies. We consider an invention to be generated in the home country of the company when at least one inventor is located there, and to be invented abroad when no inventor is located in that home country. We also approach the question from a different angle by studying the location of applicants, in order to establish whether applications are filed from the home country, either from the headquarters or domestic subsidiaries of the MNE The analysis is based on the total number of patent applications filed by the MNE, meaning the applicant may be a domestic or a foreign subsidiary. We consider an application to be filed from the home country when at least one applicant is located in the home country of the F\&B MNE, and to be filed from abroad when none of the applicants is located there.

We have removed Unilever from our analysis, as its characteristics are very different from the remaining F\&B MNEs sampled. It has: i) very high patent counts; and ii) two headquarters, one located in the Netherlands and one in the United Kingdom, making it a special case as regards the identification of its "home country". Although in this paper we classify Unilever as a Dutch company, the UK cannot truly be considered a foreign location, since it is Unilever's co-home country. ${ }^{9}$ Analysing EPO applications, the share of patent applications for inventions produced in companies' home countries was as high as $58 \%$ of total (home and abroad) applications in the period 1978-2005. With regard to US patents, this figure was 44\% in 1978-2001.

Turning now to the location of applicants, $88 \%$ of all EPO applications were filed from home countries in 1978-2005. ${ }^{10}$ The share of US patents filed from home countries tends to decrease over time, whereas the share of those filed from host countries tends to increase; however, both shares display quite irregular trends.

In summary, EPO applications tend be predominantly generated in and filed from home countries, although the results are less clear in the case of US patents, where the influence of

9 We consider Unilever to be a Dutch company, following AGRODATA, although others (e.g. the IPTS Industrial R\&D Scoreboard) classify it as a British firm. On this issue, the Unilever 2008 Annual Report states: "The two parent companies, NV and PLC, together with their group companies, operate as a single economic entity (the Unilever Group, also referred to as Unilever or the Group)" http://www.unilever.com/images/ir ar08 annual-report tcm13-163124.pdf

10 It should be remembered that we consider a patent to be filed from "home" when at least one of its applicants is located in the company's home country (in the case of Unilever, the Netherlands), and thus coapplications from Unilever PLC and Unilever NV are classified as inventions filed from home. 
foreign inventions appears to be higher. As stated earlier, most previous patent-based analyses of the internationalisation of corporate $R \& D$ have been based exclusively on the number of patents granted by the USPTO. Our results suggest that analyses which focus solely on this data source may exaggerate the importance of the internationalisation of $R \& D$ in the F\&B sector.

\subsection{Regionalisation versus globalisation of invention}

As the previous section demonstrates, the companies sampled have to some extent internationalised their inventive activities, but it remains unclear whether this has been a global or regional exercise. To explore this question further, we investigate whether companies prefer EU (home country included) or extra-EU locations for the production of inventions, analysing the 56 EU-based F\&B MNEs in our sample. We study location preferences for both EPO applications (Figure 3a) and USPTO grants (Figure 3b), and conclude in both cases that EU F\&B MNEs tend to locate their inventive activities in EU countries, although the predominance of EU locations is clearer for EPO applications than for USPTO patent grants. ${ }^{11}$ Outside the EU, the most important location for EU F\&B MNEs' innovative activities is the US.

11 Both results are reinforced when Unilever is excluded from the sample of EU F\&B MNEs. 
Figure 3: EU F\&B MNE inventions produced inside/outside the EU

Figure 3a. EPO applications: inventions produced inside/outside EU-27 Home country included. Filing years 1978-2005

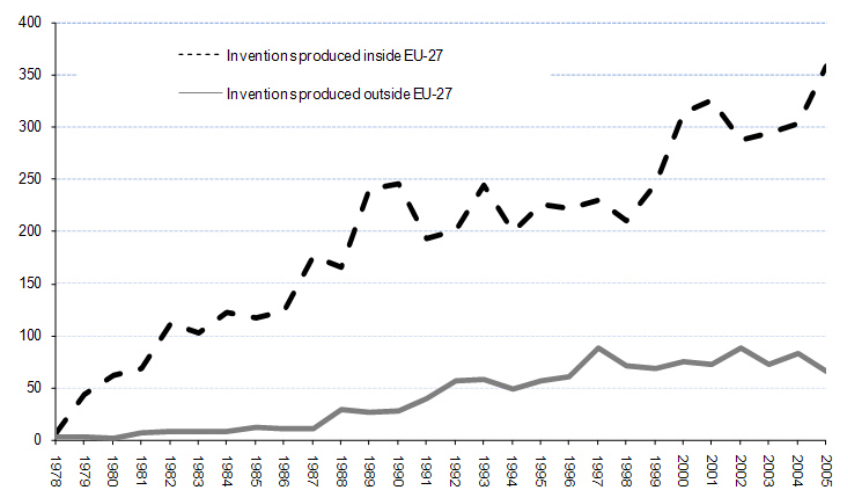

Figure 3b. USPTO patent grants: inventions produced inside/outside EU-27 Home country included. Filing years 1978-2001

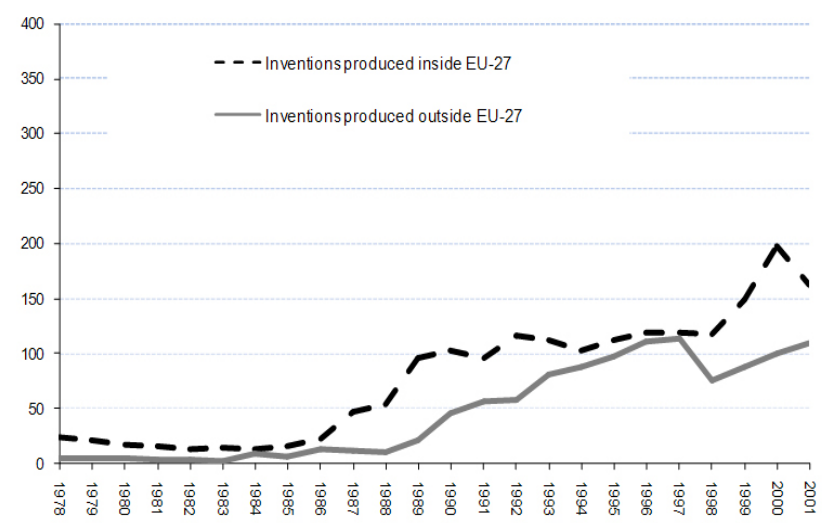

Notes: "Inventions produced inside EU-27": at least one inventor is located inside the EU-27; "Inventions produced outside EU-27": no inventor is located inside the EU-27. Based on the total number of patent applications filed by the MNE group (including all its domestic and foreign subsidiaries).

Source: Own elaboration, based on patent data from PATSTAT September 2008 and information on subsidiaries from BvD Amadeus 2008 for a selection of Top Food European MNEs, taken from Agrodata 2005.

To separate home effects from regional effects in the internationalisation of $R \& D$, we examine the locational patterns of inventions generated in the EU-27 (excluding companies' home countries) and in the US (Unilever excluded from the sample). Once more, the analysis is based on both EPO applications (Figure 4a) and USPTO patent grants (Figure 4b). The former show that EU F\&B MNEs display a clear preference for EU countries when internationalising their R\&D activities. Data from the USPTO, however, indicate that the share of inventions produced by EU F\&B MNEs in each of these two major locations (the EU-27 and the US) varies over time, and thus no clear preference can be identified. 
Figure 4: Inventors located outside home countries: EU vs US

Figure 4a. EPO applications: inventions produced outside home country by EU F\&B MNEs Filing years 1978-2005

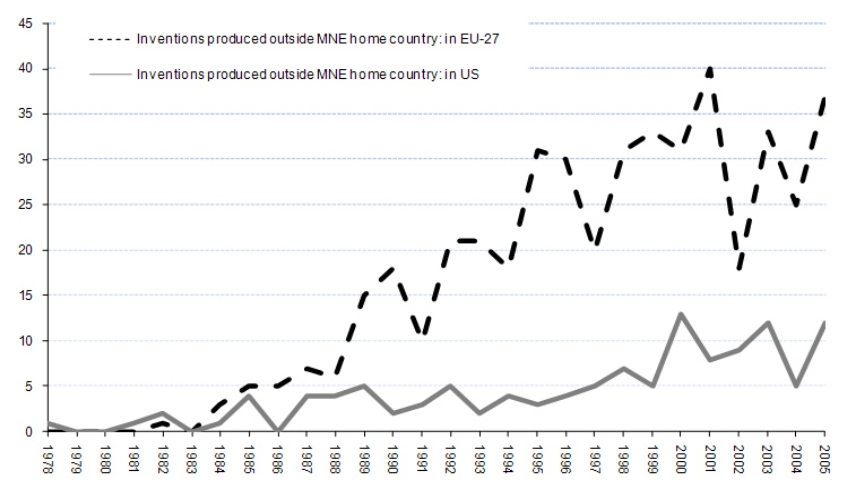

Figure 4b. USPTO patent grants: inventions produced outside home country by EU F\&B MNEs Filing years 1978-2001

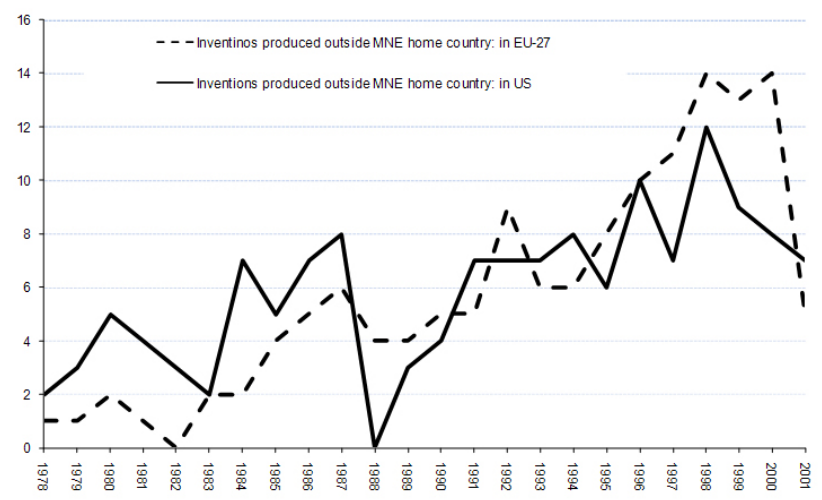

Notes: "Inventions produced outside MNE home country: in EU-27: no inventor located in the home country and at least one inventor located in an EU country (EU-27). "Inventions produced outside MNE home countries: in US": no inventor located in the home country and at least one inventor located in the United States. Based on the total number of patent applications filed by MNE group (including all its domestic and foreign subsidiaries).

Source: Own elaboration, based on patent data from PATSTAT September 2008 and information on subsidiaries from BvD Amadeus 2008 for a selection of Top Food European MNEs, taken from Agrodata 2005.

The two previous analyses have shown how the use of different indicators and time periods may influence conclusions, as earlier studies had predicted (Patel 1995). For patent counts, pending patent applications may be more appropriate than patent grants to proxy the inventive activity of firms. As stated earlier, counts are not then affected by patent office decisions regarding the granting of applications (Dernis and Khan 2004); moreover, USPTO data appear to overestimate European firms' patenting in the US (Criscuolo et al 2002). Employing solely EPO applications, we conclude that EU F\&B MNEs prefer to generate patentable inventions in their home countries, and alternatively in other EU countries. 
However, one concern may remain regarding our use of patents as a proxy for the location of innovative activities. The fact that the patent applications examined here are filed in a regional office located in Europe (i.e. close to the home countries of the companies analysed), may introduce a "home bias" into the analysis. ${ }^{12}$ To address this issue, we next analyse the location of inventors on the basis of patent families, and examine whether our hypothesis of regionalisation rather than globalisation is confirmed when counts are made of triadic patent families comprising filings in Europe, Japan and the US, or of patent families with no specific geographical restrictions (i.e. international and PCT families). Triadic patent families are widely used to reflect patent value (Dernis et al, 2001; van Zeebroeck and van Pottelsberghe, 2008), but in order to include in our analysis patents of lower value we also consider international patent families and PCT patent families as indicators of "international patent propensity" (where "international" may refer equally to two neighbouring countries or two or more major world economies distant from one another). ${ }^{13}$

Having once more excluded Unilever from the sample, our results show that European F\&B MNEs (including Swiss firms) tend to prefer their inventors to be located in the home country, for all three types of families with earliest priority years between 1978 and 2000 (results available on request). When the sample is limited to EU F\&B MNEs (including Unilever but excluding Swiss firms), EU inventors (home country included) are clearly preferred to non-EU inventors, for all three family types (Figure 5). To summarise, and in corroboration of studies of MNEs operating in other sectors (Archibugi and Michie 1995), our comparisons suggest that the foreign patenting activity of European F\&B MNEs is a regional rather than global phenomenon.

12 This may nevertheless be offset by the fact that filing patents at the EPO is an expensive process (van Pottelsberghe de la Potterie and Francois, 2009).

13 These three types of patent families are not mutually exclusive. Triadic families are a subset of international families, and both triadic and international families are also PCT families when they include a PCT international application among their members (Martínez, 2010), something more likely to occur since the 1990s, when PCT applications began to flourish (OECD, 2009). 
Figure 5: Applications for patent families by EU-based F\&B MNEs: inventions produced inside and outside the EU-27

Home country included. Earliest priority years 1978-2000.

Figure 5a. Triadic patent families

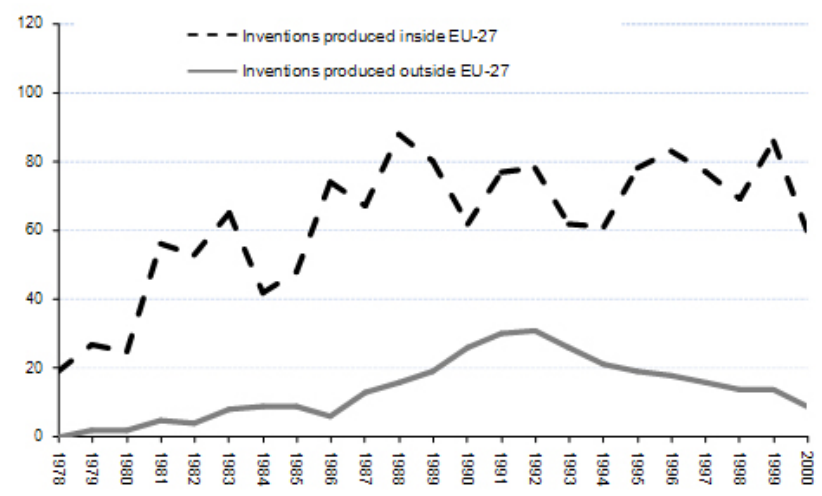

Figure 5b. International patent families

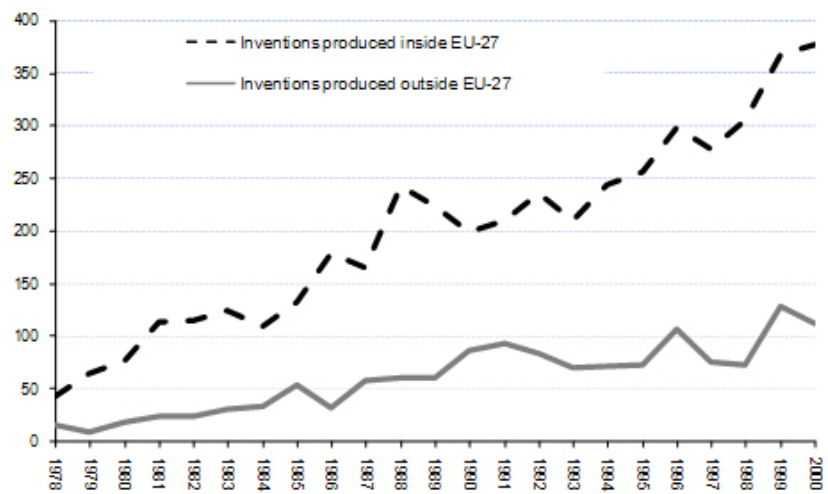

Figure 5b. PCT patent families

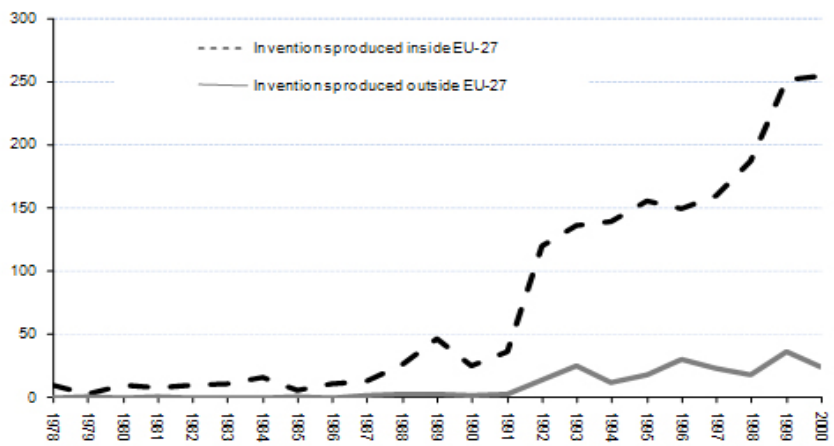

Notes: "Inventions produced inside/outside EU-27": at least one inventor is located in an EU-27 country; "Invented outside EU-27": no inventor is located in an EU-27 country. Based on the consolidated/total number of patent applications filed by MNE group (including all its domestic and foreign subsidiaries).

Source: Own elaboration, based on patent data from PATSTAT September 2008 and information on subsidiaries from BvD Amadeus 2008 for a selection of Top Food European MNEs, taken from Agrodata 2005. 


\section{INVENTION CHARACTERISTICS AND LOCATION OF INVENTORS}

It has been claimed that $R \& D$ internationalisation should be understood in qualitative rather than quantitative terms (Blanc and Sierra 1999; Cohen et al. 2009). In order to improve our understanding of exactly which (rather than how much) technology is required by companies, we evaluate the differences and similarities between the innovations developed by a subsample of EU F\&B MNEs at home and abroad, in regional (EU-27) and extra-regional (non-EU-27) locations; we employ the location of the inventor to proxy the location of the invention. We compare: i) the commercial value of inventions (as measured by the presence of triadic patent families); ii) their technical complexity (as measured by the number of inventors engaged in the production of each invention) and ii) the nature of the invention itself (food- or non- foodrelated).

We also investigate the location of R\&D centres of excellence belonging to the firms sampled, in order to determine whether the global management and control of corporate innovation is located in Europe or elsewhere. We argue that companies tend to retain the direction of innovation within Europe.

\subsection{Inventing at home or abroad}

Using triadic patents to proxy commercial value, we begin by calculating a Pearson $\chi^{2}$ statistic to test whether EU-27 F\&B MNEs tend to retain their most commercially valuable R\&D activities in their home countries. Triadic patents are considered to protect commercially valuable innovation because they are filed in the three major patent offices worldwide and cover the three vital economic areas of the United States, Europe and Japan. The cost, time and effort involved in filing patents in these three areas is taken to be an indication of the high returns applicants expect to make by protecting their inventions in the three regions, either through product commercialisation, protection from imitation, the blocking of competitors or exploiting the value of patents in other ways. Each patent (application) is thus classified as triadic or nontriadic. Secondly, patents (applications) are also classified according to the inventor's location (in the home country or abroad). Owing to the abovementioned problem of its dual nationality, we exclude Unilever from the analysis.

Our results are not conclusive. Employing USPTO grants, we find no statistically significant association between patent type (triadic or non-triadic) and inventor location (Table 2). When studying EPO applications, Cramer's V, which measures the effect size, indicates a very weak association between the variables.

We next test whether EU-based F\&B MNEs produce their more technologically complex (and possibly costlier) innovations at home. As a proxy for R\&D process complexity, we use the number of inventors involved in the production of each innovation. The variable takes the value of 0 when the innovation involves less than three inventors and the value of 1 when it involves 
three or more. ${ }^{14}$ Whichever data source is used (USPTO patent grants or EPO applications), we find no association between innovation complexity and the location of its producers in the company's home country. Finally, we test whether strategic inventions (food-related inventions for F\&B MNEs) tend to be produced at home, by dividing both USPTO patent grants and EPO applications into food- and non-food-related innovations ${ }^{15}$. We calculate a Pearson $\chi^{2}$ statistic to compare the frequency of food and non-food patents (applications) in each inventor's location (home and abroad). Again, results are not conclusive (Table 2). To summarise, the commercial value, technical complexity and strategic nature of inventions are apparently unrelated to whether their producers are located in the MNE's home country or abroad.

Table 2. Invention characteristics and inventor location (home or abroad)

EU-based food and beverage multinationals (Unilever excluded)

\begin{tabular}{|c|c|c|c|c|}
\hline Invention type & $\chi^{2}$ & Exact 2-sided & Cramer's V & $\mathbf{N}$ \\
\hline \multicolumn{5}{|c|}{ USPTO patent grants (filing years 1978-2001) } \\
\hline $\begin{array}{c}\text { Triadic } \\
(\text { Yes/No) } \\
\end{array}$ & $2.689(1)$ & 0.118 & $\begin{array}{c}0.062 \\
(0.101) \\
\end{array}$ & 710 \\
\hline $\begin{array}{c}\text { At least three inventors } \\
(\mathrm{Yes} / \mathrm{No})\end{array}$ & $0.505(1)$ & 0.519 & $\begin{array}{c}0.026 \\
(0.477) \\
\end{array}$ & 710 \\
\hline Food-related (Yes/No) & $0.950(1)$ & 0.356 & $\begin{array}{c}0.035 \\
(0.330)\end{array}$ & 757 \\
\hline \multicolumn{5}{|c|}{ EPO patent applications (filing years 1978-2005) } \\
\hline $\begin{array}{c}\text { Triadic } \\
(\text { Yes/No }) \\
\end{array}$ & $5.013(1)$ & 0.027 & $\begin{array}{c}0.54 \\
(0.025) \\
\end{array}$ & 1,748 \\
\hline $\begin{array}{l}\text { At least three inventors } \\
(\mathrm{Yes} / \mathrm{No})\end{array}$ & $0.031(1)$ & 0.854 & $\begin{array}{c}0.004 \\
(0.860) \\
\end{array}$ & 1,782 \\
\hline Food-related (Yes/No) & $5.104(1)$ & 0.025 & $\begin{array}{c}0.054 \\
(0.024) \\
\end{array}$ & 1,775 \\
\hline
\end{tabular}

Source: Authors' calculations.

\subsection{Inventing inside or outside the EU-27}

In order to detect possible regional effects, we now investigate whether EU-based F\&B MNEs tend to retain their most commercially valuable $R \& D$ activities in regional locations i.e. within the EU-27 (home country included). Unilever is included in this analysis since its dual nationality does not affect the results concerning the regional or extra-regional location of the inventor, both its parent companies being located in EU countries.

F\&B MNEs may plan their R\&D activities on a supra-national scale, possibly retaining within the EU their most valuable R\&D activities or those which are most closely related to their core business. Once more, we use triadic families to proxy the commercial value of patents, classified according to inventor location (inside or outside the EU-27).

14 The average patent lists approximately three inventors.

15 Food-related inventions are defined as those having at least one IPC class within the technology subfields "Food and Agriculture" or "Food and Agriculture Machines \& Tools" of the 30 technology subclasses established in the 2nd revision of the IPC correspondence OST-INPI/FhF-ISI. Non-food-related inventions are those without an IPC class in these two subfields. 
Again, our results are not conclusive. Employing either USPTO or EPO data, we find significant statistical associations between patent type (triadic or non-triadic) and inventor location (intraor extra-EU) (Table 3). However, according to EPO data, most inventions produced in the EU (70.4\%) are non-triadic while, according to USPTO data, most inventions produced in the EU are triadic $(56.5 \%) .{ }^{16}$ No matter which data source is used, Cramer's V, which measures the effect size, is low and suggests very weak association between the variables.

We also test whether EU-based F\&B MNEs tend to produce their technologically complex innovations within the EU-27. As a proxy for R\&D process complexity, we again employ the number of inventors involved in the production of an innovation. Once more, our results are not conclusive, owing to discrepancies between sources and small size effects (Table 3 ).

Finally, we test whether EU-based F\&B MNEs retain their strategic inventions (i.e. food-related inventions) within the EU-27. We calculated a Pearson $\chi^{2}$ statistic to compare the frequencies of food and non-food patents (applications) in each inventor's location (EU-27 and non-EU-27). Whether employing USPTO or EPO data, we found statistically significant relationships between invention type and inventor location; Cramer's V indicates weak to moderate relationships between the variables. According to USPTO data, 31.6\% of the inventions produced within the EU-27 are food-related (compared to only $11.5 \%$ of those produced in extra-regional locations). In turn, EPO data show that $33.7 \%$ of the inventions produced within the EU-27 are foodrelated (compared to only $14.0 \%$ of those produced in extra-regional locations).

To summarise, the commercial value and complexity of innovations appear to be unrelated to the location of the inventor (i.e. inside or outside the EU-27). Secondly, the data suggest that European F\&B MNEs tend to retain their food-related R\&D activities within the EU-27.

Table 3. Invention characteristics and inventor location (regional or extra-regional) EU-based food and beverage multinationals (Unilever included)

\begin{tabular}{|c|c|c|c|c|}
\hline Type of invention & $\chi^{\mathbf{2}}$ & Exact 2-sided & \multicolumn{3}{|c|}{ Cramer's V } & N \\
\hline USPTO patent grants (filing years 1978-2001) & \multicolumn{3}{|c|}{$\begin{array}{c}0.097 \\
(0.000)\end{array}$} & 2,280 \\
\hline $\begin{array}{c}\text { Triadic } \\
\text { (Yes/No) }\end{array}$ & $28.522(1)$ & 0.000 & $\begin{array}{c}0.038 \\
(0.036)\end{array}$ & 3,001 \\
\hline $\begin{array}{c}\text { At least three inventors } \\
\text { (Yes/No) }\end{array}$ & $4.397(1)$ & 0.039 & $\begin{array}{c}0.227 \\
(0.036)\end{array}$ & 2,995 \\
\hline $\begin{array}{c}\text { Food-related (Yes/No) } \\
\text { EP patent applications (filing years 1978-2005) }\end{array}$ & $154.942(1)$ & 0.000 & $\begin{array}{c}0.160 \\
(0.000)\end{array}$ & 6,513 \\
\hline $\begin{array}{c}\text { Triadic } \\
\text { (Yes/No) }\end{array}$ & $166.476(1)$ & 0.000 & $\begin{array}{c}0.030 \\
(0.015)\end{array}$ & 6,615 \\
\hline $\begin{array}{c}\text { At least three inventors } \\
\text { (Yes/No) }\end{array}$ & $5.888(1)$ & 0.016 & $\begin{array}{c}0.166 \\
(0.000)\end{array}$ & 6,510 \\
\hline \begin{tabular}{c} 
Food-related (Yes/No) \\
\hline
\end{tabular}
\end{tabular}

Source: Authors' calculations.

16 This may be partly due to the fact that the EPO is geographically closer than the USPTO to the home countries of the sampled companies, and would therefore be their first choice for the international extension of domestic patents. 


\section{3. $R \& D$ control and management: location of $R \& D$ subsidiaries}

We now study the location of F\&B MNE subsidiaries which specialise in R\&D (NACE 7310), using information provided by AMADEUS. The sampled companies own 38 subsidiaries specialising in $R \& D$; it should be emphasised that these subsidiaries enjoy independent status and are not merely laboratories attached to MNE production facilities.

From our sample of 59 European F\&B MNEs, only 17 companies owned such centres in 2005, although some (e.g. Nestlé or Danisco) owned several. Our results are coherent with a study of $\mathrm{F} \& \mathrm{~B}$ MNE subsidiaries specialising in $\mathrm{R} \& \mathrm{D}$, technology transfer and high-tech products such as nutraceuticals (Filippaios et al. 2009); the study suggests that companies which display substantial country spread, such as Nestlé, are more likely to adopt this type of R\&D organisation, as an effective tool for the coordination and centralisation of their worldwide innovative activities. F\&B MNEs based in the EU and Switzerland locate their R\&D subsidiaries exclusively in three areas: i) the EU-27, ii) other Western European countries (Norway and Switzerland) and iii) the US (Figure 6). Within the EU, the most important locations for such subsidiaries are Denmark and the United Kingdom. By the late 1980s the United Kingdom was the European location of preference for the research-related subsidiaries of the world's largest F\&B MNEs (Rama 1996). Developing nations, such as China and Latin American countries, attract a substantial share of FDI in this industry (Tozanli 2005) but have been unable to attract R\&D subsidiaries, probably as a result of insufficiently developed National Systems of Innovation and, more specifically, the weaknesses of their sectoral systems of innovation (Alcorta and Peres 1998; Cabral and Rama 2008 ; Christensen, Rama and von Tunzelmann 1996). We conclude that European F\&B MNEs prefer to locate within Europe those specialised subsidiaries which coordinate and control innovative activities across the multinational network. This result also supports our hypothesis that the internationalisation of $R \& D$ is, at least among European F\&B MNEs, a regional rather than global phenomenon. 
Figure 6. Location of R\&D subsidiaries of European F\&B MNEs

Percentage of total

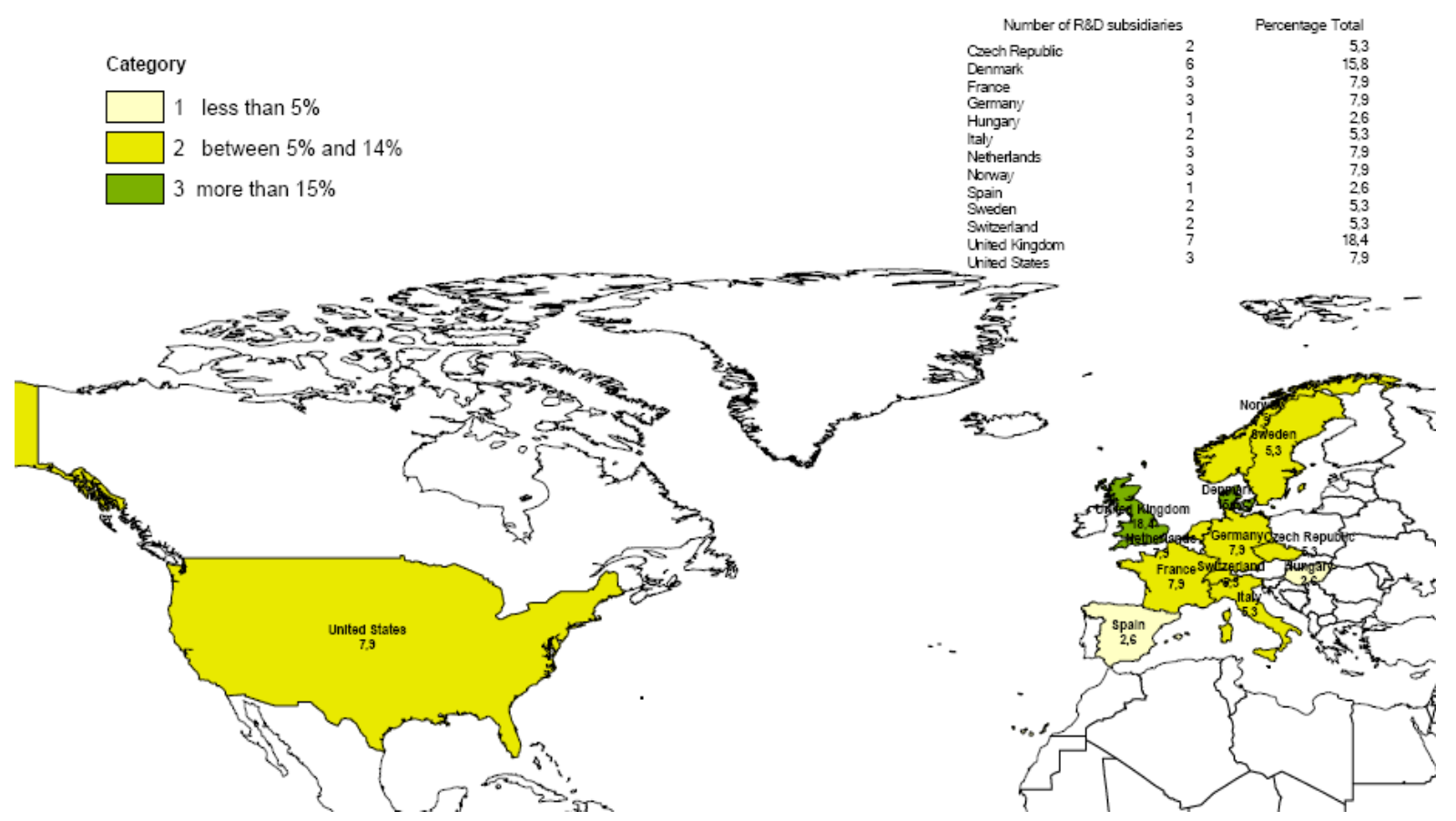

Source: Authors'calculations

\section{Conclusions}

We have investigated whether the largest European food and beverage MNEs tend to produce their patentable innovations in their home countries or abroad. To address this question we constructed a database comprising 59 major companies, of which 56 are based in the EU-27 and 3 in Switzerland, and their 8,432 subsidiaries. To study their R\&D activities we employed a variety of indicators: i) 8,626 EPO applications filed by these companies in 1978-2005; ii) 3,650 US patents they applied for in 1978-2001; iii) three different types of patent families and iv) the location of their R\&D centres of excellence.

Firstly, based on a descriptive analysis of the evolution of corporate patenting trends, we conclude that EPO patent applications filed by the F\&B MNEs sampled are most frequently generated within companies' home countries, and within the EU if they are produced abroad. This observation is strongly confirmed when using different types of patent family indicators (to eliminate the possible "home bias" associated with EPO data), but not when employing USPTO patent grants data, which show foreign locations to be more important. In our view, this indicates that analyses which rely solely on USPTO data may have exaggerated the importance of R\&D internationalisation. We also argue that the use of data on pending patent applications (taken either from a single office such as the EPO or from patent families) is more suitable for the analysis of corporate inventions, since the study of only those applications which are successful (e.g. USPTO patent grants) can only provide an incomplete view of the subject (Dernis, 2004). 
Secondly, we employed several statistical tests to establish the location preferred (home or abroad) for the most valuable, complex or strategic corporate R\&D; analysing the location of inventors, we find that the share of triadic patents is similar at home and abroad. We also find that the share of inventions involving at least three inventors is similar at home and abroad. Finally, we find that the share of foodrelated patents is similar at home and abroad.

Thirdly, we attempted to establish the location preferred (inside or outside the EU-27) for valuable, complex or strategic corporate $R \& D$. We are unable to reject the null hypotheses that the production of triadic patents and inventions involving at least three inventors are similar in the EU-27 and elsewhere. Conversely, we find that F\&B MNEs tend to retain those R\&D activities most closely related to their core business (food) within the EU-27. Our results do not support the thesis that companies retain their most strategic research (in this case, food-related research) near their headquarters (Criscuolo et al 2002), although they prefer to develop it within the EU. Finally, we find that European F\&B MNEs locate their R\&D centres of excellence within rather than outside Europe.

European F\&B MNEs display regional strategies with regard to the internationalisation of their manufacturing facilities (Filippaios and Rama 2008); their intensive intra-firm trade within the EU suggests that they promote production and marketing inter-complementarities among their regional subsidiaries (Galiano et al 2005). Our results suggest that firms may also organise their most strategic R\&D activities (i.e. food-related inventions) from a regional perspective; they may be drawing strategic knowledge related to food production from the EU rather than solely the home country. Companies prefer to locate their technical expertise in food sciences within the EU-27, an option which suggests that regional sectoral systems of innovation provide their laboratories with sufficient support. Some of these issues require further future investigation, yet our preliminary results indicate the need for improved intra-EU coordination of food research and of education in agriculture and food science. Such measures could increase the internal R\&D capabilities of not only the large MNEs sampled here but also those of smaller European F\&B companies still on the path towards internationalisation.

We also find that EU-based F\&B MNEs tend to produce their non-food innovation in extra-regional locations. Non-food innovation may account for companies' incursions into technologies relatively new to them; corporate activity in such fields is probably best characterised as Home Based Augmenting (HBA) technological activities, as described by various authors (e.g. Kuemmerle 1999). If this classification is accurate, our results confirm the thesis that MNEs tend to perform HBA activities abroad (in this case, in extra-regional locations).

Given the substantial industrial diversification of F\&B MNEs (Anastassopoulos and Rama 2005), their non-food technology requirements may involve a variety of technical fields. As it is impossible for any nation or supra-national region to excel in all technological fields, our results do not necessarily indicate a weakening of European systems of innovation. Logically enough, EU-based F\&B MNEs may prefer to locate some of their non-food R\&D activities in specialised foreign agglomerations. However, our results suggest various reasons for concern. Firstly, non-food R\&D activities account for the largest and most dynamic share of such companies' innovative activities. Secondly, as some authors 
have suggested (Alfranca et al 2003), European F\&B MNEs may be involved, in part, in nonfood R\&D because they need to research important inputs required to produce food (and not necessarily because of their industrial diversification). Food production nowadays involves a broad spectrum of sciences and techniques, ranging from biotechnology to specialised software and instruments (Christensen et al 1996). The preference of European F\&B MNEs for foreign locations with regard to non-food technology may point to European weaknesses in such important technical fields. A strengthening, within the EU 27, of non-food research specifically required for food production may be desirable, in order to attract indigenous F\&B MNEs and their laboratories and to increase the competitiveness of European food and drink companies.

The research presented here indicates several paths for further investigation, both to refine our database and to analyse invention characteristics in greater depth, employing a variety of patent indicators and corporate information. We believe it would be useful: i) to extract data on subsidiaries at different points in time, in order to take account of temporal changes in the corporate structure of the firms sampled; ii) to explore patterns of cooperation in the ownership (co-application) and production (co-invention) of patented inventions; iii) to analyse patent families more deeply; and iv) to investigate further the nature of innovations unrestricted by the food/non-food distinction. We shall explore these lines of research in future work. 


\section{ACKNOWLEDGEMENTS}

We thank Stéphane Maraut for having developed the matching algorithms needed to assign patents to MNE groups. We also thank Juan Fernández-Sastre for research assistance, and José Manuel Rojo for his help with the data. Ruth Rama gratefully acknowledges support provided by the PRIME project of the European Union. 


\section{REFERENCES}

1. Abramovsky, L., R. Griffith, G. Macartney and H. Miller (2008). 'The location of innovative activity in Europe'. The Institute for Fiscal Studies. WP 08/10.

2. Alcorta, L., and W. Peres. (1998). 'Innovation systems and technological specialization in Latin America and the Caribbean'. Research Policy (26),857-881.

3. Alfranca, O., R. Rama, and N. von Tunzelmann. (2002). 'A patent analysis of global food and beverage firms: the persistence of innovation’. Agribusiness. An International Journal (18).

4. - - (2003). 'Technological fields and concentration of innovation among food and beverage multinationals'. International Food and Agribusiness Management Review (5),

5. - - (2004). 'Combining different brands of in-house knowledge: technological capabilities in food, biotechnology, chemicals and drugs in agri-food multinationals'. Science and Public Policy (31), 227-244.

6. - - (2005). 'Innovation in food and beverage multinationals'. in, R. Rama (ed). Multinational agribusinesses. New York and London: Haworth Press Inc.

7. Anastassopoulos, G. and R. Rama (2005). 'The performance of multinational agribusinesses: effects of product and geographical diversification', pp.73-113 in Multinational agribusiness, edited by R. Rama. New York and London: Haworth Press Inc.

8. Archibugi, A., and S. Iammarino. (1999). 'The policy implications of the globalisation of innovation'. Research Policy (28),317-336.

9. Archibugi, D. , and J. Michie. (1995). 'The globalisation of technology: a new taxonomy'. Cambridge Journal of Economics (19),121-140.

10. Basberg, B. (1987).'Patents and the measurement of technological change: a survey of the literature'. Research Policy (16), 131-141.

11. Belberdos, R. (2001) 'Overseas innovations by Japanese firms: an analysis of patent data and subsidiary data’, Research Policy (30), 313-332.

12. Bijman, W..B., R. van Tulder, and M. van Vliet. (1997). 'Internationalisation of Dutch Agribusiness and the Organisation of R\&D.’ Pp. 10 in Seminar on Globalization of the Food Industry:, University of Reading, Reading.

13. Blanc, H., and C. Sierra. (1999). 'The internationalisation of R\&D by multinationals: a trade-off between external and internal proximity'. Cambridge Journal of Economics (23),187-206.

14. Cabral, J.E. de O., and R. Rama. (2008 ). 'Technological Innovation in the Brazilian Food and Beverage Industry'. in, R. Rama (ed). Handbook of innovation in the food and drink industry. New York and London: Taylor \& Francis Group.

15. Cantwell, J. , and C. Hodson. (1991). 'Global R\&D and UK competitiveness'. Pp. 133-183 in, Mark Casson (ed). Global Research Strategy and International Competitiveness. Oxford and Cambridge: Basil Blackwell.

16. Cantwell, J., and S. Iammarino. (2000). 'Multinational corporations and the location of technological innovation in the UK regions'. Regional Studies (34),317-332.

17. Cantwell, J., and O. Janne. (1999). 'Technological globalization and innovative centres: the role of corporate technological leadership and locational hierarchy’. Research Policy (28),119-144.

18. - (2000). 'Globalization of innovatory capacity: the structure of competence accumulation in European home and host countries'. Pp. 121-177 in, F. Chesnais, G. Ietto-Gillies, and R. Simonetti (ed). European integration and global corporate strategies. London-NY: Routledge.

19. Cantwell, J., and E. Kosmopoulou. (2001). 'Determinants of internationalisation of corporate technology.' Pp. 35 in DRUID Working Papers.

20. Cantwell, J., and L. Piscitello. (1999). 'The emergence of Corporate International Networks for the accumulation of dispersed technological competences'. MIR 123-147.

21. Cantwell, J., and G. D. Santangelo. (1999). 'The frontier of international technology networks: sourcing abroad the most highly tacit capabilities'. Information Economics and Policy (11),101-123. 
22. Chevassus-Lozza, E., Gallezot, J., \& Galliano, D. (2005). External versus internal markets of the multinational enterprises: intrafirm trade in French multinational agribusiness. In R. Rama (Ed.), Multinational Agribusinesses (pp. 191-218). N.Y. and London: Haworth Press Inc.

23. Christensen, J. L., R. Rama, and N. von Tunzelmann. (1996). 'Study on innovation in the European Food Products and Beverages Industry.' Pp. 145. EIMS/SPRINT Brussels: The European Commission.

24. Cohen, S.S., A. Di Minin, Y. Motoyama, and C. Palmberg. (2009). 'The persistence of home bias for important R\&D in wireless telecom and automobiles’. Review of Policy Research (26),55-77.

25. Criscuolo, P., R. Narula and B. Verspagen (2002). 'The relative importance of home and host innovation systems in the internationalisation of MNE R\&D: a patent citation analysis'. Eindhoven Center for Innovation Studies. Working Paper 02.20.

26. Dernis, H., D. Guellec and B. van Pottelsberghe de la Potterie (2001). 'Using patent counts for cross-country comparisons of technology output', OECD STI review, 27, OECD, Paris.

27. Dernis, H. and M. Khan (2004). 'Triadic patent families methodology', OECD STI Working Paper 2004/2, OECD, Paris.

28. Doz, Y.L. (2005). 'A commentary on innovation systems in small open economies in light of the Sweedish, Israeli, Finnish and Singaporean experiences’. Pp. 101-105 in, P. Larédo and F. Sachwald (ed). Le système français d'innovation dans l'économie mondiale: enjeux et priorités. Paris: IFRI-Institut de l'Entreprise.

29. Dunning, J., and R. Narula. (1996). 'The investment development path revisited: some emerging issues'. in, J. Dunning and R. Narula (ed). Foreign Direct Investment and governments. Catalysts for economic restructuring. London and N.Y.: Routledge.

30. Dunning, J.H. (1994). 'Multinational enterprises and the globalization of innovatory capacity'. Research Policy (23), 67-68.

31. Dunning, J.H., and S.M. Lundan. (2009). 'The internationalization of corporate R\&D: A review of the evidence and some policy implications for home countries'. Review of Policy Research (26), 13-34.

32. Edler, J. (2008). 'Creative internationalization: widening the perspectives on analysis and policy regarding international R\&D activities’. Journal of Technology Transfer (33), 337-352.

33. Filippaios, F., R. Pearce, M. Papanastassiou, and R. Rama. (2009). 'New forms of organisation and R\&D internationalisation among the world's 100 largest food and beverages multinationals'. Research Policy (38), 1032-1043.

34. Galizzi, G., and L. Venturini. (2008). 'Nature and determinants of product innovation in a competitive environment of changing vertical relationships'. in, Ruth Rama (ed). Handbook of innovation in the food and drink industry. New York and London: Taylor \& Francis Group.

35. Gassmann, O., and M. von Zedtwitz. (1998). 'Organization of industrial R\&D on a global scale'. R\&D Management (28), 147-161.

36. Gerybadze, A., and G. Reger. (1999). 'Globalization of R\&D: recent changes in the management of innovation in transnational corporations’. Research Policy (28),251-274.

37. Griliches, Z. (1990). 'Patent statistics as economic indicators: a survey', Journal of Economic Literature, 28, 1661-1707.

38. Grupp, H., G. Münt, and U. Schmoch (1996). 'Assessing different types of patent data for describing hightechnology export performance’, in Innovation, Patents and Technological Strategies, pp.271-287, OECD, Paris.

39. Grupp, H. (1998). Foundations of the Economics of Innovation. Theory, measurement and practice. Edward Elgar Publishing Ltd. Cheltenham, UK.

40. Guellec, D. and B. van Pottelsberghe de la Potterie (2004). 'Measuring the globalisation of technology. An approach based on patent data', CEB Working Paper 04-13.

41. Hu, Y.-S. (1992). 'Global or Stateless Corporations Are National Firms with International Operations'. California Management Review (34),107-126.

42. Kuemmerle, W. (1999). 'Foreign direct investment in industrial research in the pharmaceutical and electronic industries-results from a survey of multinational firms'. Research Policy (28) 179-93. 
43. Le Bas, C. and C. Sierra (2002). 'Location versus home country advantages' in R\&D activities: some further results on multinationals’ locational strategies’. Research Policy (31), 589-609.

44. Martínez, C. (2010), 'Insight into different types of patent families', OECD STI Working Paper 2010/2.

45. Meyer-Krahmer, V.F., and G. Reger. (1999). 'New perspectives on the innovation strategies of multinational enterprises: lessons for technology policy in Europe'. Research Policy (28),751-776.

46. Narula, R. (2000). 'Explaining "inertia" in R\&D internationalisation: Norwegian firms and the role of home country-effects.' Pp. 1-39 in Research Memoranda, edited by Maastricht Economic Research Institute on Innovation and Technology. Maastricht.

47. OECD (2005). 'Background report. Internationalisation of R\&D: Trends, issues and implications for S\&T policies. A review of the literature.' Pp. 1-67. Brussels: OECD Forum on the Internationalisation of R\&D.

48. OECD (2009), Patent Statistics Manual, OECD, Paris.

49. Patel, P. (1995). 'Localised production of technology for global markets'. Cambridge Journal of Economics (19), 141-153.

50. Patel, P., and K. Pavitt. (1991). 'Large firms in the production of the world's technology: an important case of 'non-globalisation'. Journal of International Business Studies (22), 1-21.

51. Patel, P., and M. Vega. (1999). 'Patterns of internationalisation of corporate technology: location vs. home country advantages’. Research Policy (28), 145-155.

52. Patel, P., and K. Pavitt. (1995). 'Patterns of technological activity: their measurement and interpretation'. in, P. Stoneman (ed). Handbook of the Economics of Innovation and Technological Change. Blackwell.

53. - (1997). 'The technological competencies of the world's largest firms: complex and path-dependent, but not much variety'. Research Policy 141-156.

54. Pearce, R. (1999). 'Decentralised R\&D and strategic competitiveness: globalised approaches to generation and use of technology in multinational enterprises (MNEs)'. Research Policy (28),157-178.

55. Pearce, R., and M. Papanastassiou. (1999). 'Overseas R\&D and the strategic evolution of MNEs: evidence from laboratories in the UK'. Research Policy (28),23-41.

56. Quintás, M., X. H. Vázquez, J.M. García and G. Caballero (2008). 'Geographical amplitude in the international generation of technology: present situation and business determinants'. Research Policy (37), 1371-1381.

57. Rama, R. (1996). 'Les multinationales et l'innovation. Localisation des activités technologiques de l'agroalimentaire'. Economie Rurale. Paris (231),62-68.

58. - (1999). 'Innovation and profitability of global food firms. Testing for differences in the influence of the home-base'. Environment and planning (31), 735-751.

59. Reddy, P. (1993). 'Emerging patterns of internationalization of corporate R\&D: opportunities for developing countries?’ Pp. 78-101 in, C. Brundenius and G. Göransson (ed). New technologies and global restructuring. The Third World at a crossroads. L.A.: Taylor Graham.

60. Sachwald, F. (2005). 'Mondialisation et attractivité de la France pour la R\&D des entreprises'. in, P. Larédo and F. Sachwald (ed). Le système français d'innovation dans l'économie mondiale: enjeux et priorités. Paris: IFRI-Institut de l'Entreprise.

61. Serapio, M.G., H. Takabumi, and D. Dalton. (2004). 'Internationalization of Research and Development: Empirical trends and theoretical perspectives'. in, M.G. Serapio and H. Takabumi (ed). Internationalization of Research and Development and the emergence of global R\&D networks. Amsterdam: Elsevier.

62. Tozanli, S. (2005). 'The rise of global enterprises in the world's food chain'. in, R. Rama (ed). Multinational Agribusinesses. N.Y.: Haworth Press Inc.

63. UNCTAD. (2005). 'Wold Investment Report 2005. Transnational corporations and the internationalization of R\&D.’ Pp. 331. New York and Geneva: United Nations.

64. van Pottelsberghe de la Potterie, B. and François, D. (2009). 'The Cost Factor in Patent Systems'. Journal of Industry, Competition and Trade, 9, 4, 329-355. 
65. van Zeebroeck, N. and B. van Pottelsberghe de la Potterie (2008). 'Filing strategies and patent value'. CEB Working Paper 08-016 and CEPR Discussion Paper 6821.

66. von Tunzelmann, G.N. (1998). 'Localized technological search and multi-technology companies'. Economics of Innovation and New Technology (6),231-255.

67. von Zedtwitz, M., O. Gassmann, and R. Boutellier. (2004). 'Organizing global R\&D, challenges and dilemmas'. Journal of International Management (10), 21-49. 


\section{ANNEX}

Table A1. Rankings of European food and beverage multinationals in terms of patenting

\begin{tabular}{|c|c|c|c|c|c|c|}
\hline Name & $\begin{array}{l}\text { Home } \\
\text { country }\end{array}$ & $\begin{array}{c}\text { US patent } \\
\text { grants } \\
\text { Filing years } \\
\text { 1978-2001 }\end{array}$ & $\begin{array}{c}\text { EPO } \\
\text { applications } \\
\text { Filing years } \\
\text { 1978-2005 }\end{array}$ & $\begin{array}{c}\text { Triadic } \\
\text { families } \\
\text { Earliest } \\
\text { priority years } \\
1978-2000\end{array}$ & $\begin{array}{c}\text { International } \\
\text { families } \\
\text { Earliest } \\
\text { priority years } \\
\text { 1978-2000 }\end{array}$ & $\begin{array}{c}\text { PCT families } \\
\text { Earliest } \\
\text { priority } \\
\text { years } 1978- \\
2000\end{array}$ \\
\hline Unilever & Netherlands & 1 & 1 & 1 & 1 & 1 \\
\hline Nestlé & Switzerland & 2 & 2 & 2 & 2 & 2 \\
\hline Diageo & UK & 3 & 12 & 10 & 10 & 12 \\
\hline Danisco & Denmark & 4 & 3 & 3 & 3 & 3 \\
\hline Pernod Ricard & France & 5 & 7 & 4 & 4 & 5 \\
\hline Sabmiller & UK & 6 & 21 & 14 & 19 & 11 \\
\hline Heineken & Netherlands & 7 & 5 & 5 & 8 & 6 \\
\hline Südzucker & Germany & 8 & 14 & 15 & 14 & 7 \\
\hline Danone & Erance & 9 & 4 & 6 & 6 & 4 \\
\hline Ferrero & Italy & 10 & 6 & 7 & 5 & 10 \\
\hline Numico & Netherlands & 11 & 9 & 18 & 21 & 8 \\
\hline Tate Lyle & UK & 12 & 24 & 28 & 29 & 26 \\
\hline Campina & Netherlands & 13 & 8 & 12 & 7 & 9 \\
\hline Bongrain & Erance & 14 & 11 & 11 & 9 & 25 \\
\hline Premier Foods & UK & 15 & 15 & 9 & 11 & 15 \\
\hline Oetker & Germany & 16 & 13 & 13 & 16 & 18 \\
\hline Scottish Newcastle & UK & 17 & 17 & 20 & 12 & 13 \\
\hline Carlsberg & Denmark & 18 & 26 & 17 & 24 & 17 \\
\hline United Biscuits & UK & 19 & 18 & 22 & 15 & 14 \\
\hline Kerry & Ireland & 20 & 23 & 19 & 27 & 20 \\
\hline Associated. British Foods & UK & 21 & 27 & 23 & 25 & 21 \\
\hline Sodiaal Union & Erance & 22 & 22 & 21 & 22 & 19 \\
\hline Eckes & Germany & 23 & 25 & 31 & 20 & 35 \\
\hline INBEV & Belgium & 24 & 20 & 32 & 23 & 24 \\
\hline LVMH & France & 25 & 30 & 27 & 28 & 23 \\
\hline Arla Foods & Denmark & 26 & 29 & 29 & 26 & 29 \\
\hline Koninklijke Wessanen & Netherlands & 27 & 50 & 55 & 45 & 55 \\
\hline Barry Callebaut & Switzerland & 28 & 33 & 26 & 35 & 31 \\
\hline RHM & UK & 29 & 19 & 8 & 17 & 16 \\
\hline Nutreco & Netherlands & 30 & 31 & 54 & 30 & 28 \\
\hline Barilla & Italy & 31 & 10 & 16 & 13 & 30 \\
\hline CSM & Netherlands & 32 & 16 & 24 & 18 & 22 \\
\hline Parmalat & Italy & 33 & 28 & 56 & 31 & 56 \\
\hline Provimi & France & 34 & 35 & 33 & 38 & 33 \\
\hline Uniq & UK & 35 & 36 & 34 & 32 & 59 \\
\hline Allied Domecq & UK & 36 & 46 & 37 & 47 & 37 \\
\hline Cremonini & Italy & 37 & 41 & 41 & 41 & 41 \\
\hline Danish Crown & Denmark & 38 & 32 & 25 & 34 & 27 \\
\hline Fromageries Bel & France & 39 & 44 & 47 & 39 & 47 \\
\hline Glanbia & Ireland & 40 & 55 & 49 & 54 & 49 \\
\hline Perfetti Van Melle & Italy & 41 & 39 & 57 & 40 & 36 \\
\hline Dairy Crest & UK & 42 & 38 & 42 & 33 & 42 \\
\hline $\mathrm{DCC}$ & Ireland & 43 & 42 & 35 & 42 & 34 \\
\hline Greencore & Ireland & 44 & 45 & 36 & 44 & 50 \\
\hline Barwa & Germany & 45 & 37 & 38 & 37 & 38 \\
\hline Castel Freres & Erance & 46 & 52 & 39 & 48 & 39 \\
\hline Cecab & Erance & 47 & 53 & 40 & 49 & 40 \\
\hline Ebro Puleva & Spain & 48 & 34 & 30 & 36 & 32 \\
\hline Emmi & Switzerland & 49 & 43 & 43 & 50 & 43 \\
\hline Evialis & Erance & 50 & 47 & 44 & 51 & 44 \\
\hline Fazer & Finland & 51 & 48 & 45 & 52 & 45 \\
\hline Friesland Foods & Netherlands & 52 & 54 & 46 & 53 & 46 \\
\hline Fyffes & Ireland & 53 & 49 & 48 & 43 & 48 \\
\hline Humana Milchunion & Germany & 54 & 56 & 50 & 55 & 51 \\
\hline IAWS & UK & 55 & 57 & 51 & 56 & 52 \\
\hline Lantmannen Maskin & Sweden & 56 & 58 & 52 & 57 & 53 \\
\hline Northern Foods & UK & 57 & 51 & 53 & 58 & 54 \\
\hline SOS Cuetara & Spain & 58 & 40 & 58 & 46 & 57 \\
\hline Soufflet & Erance & 59 & 59 & 59 & 59 & 58 \\
\hline \multicolumn{2}{|l|}{ TOTAL } & 3,650 & 8,626 & 2,662 & 5,993 & 2,462 \\
\hline
\end{tabular}

Source: Authors' calculations, based on PATSTAT September 2008. 
1. Cruz Castro, L. y Sanz Menéndez, L. Endogamia, Productividad y Carreras Académicas.

2. Corrochano, D. Guía Bibliográfica sobre Inmigración en España (1990-2009). Datos y Reflexiones sobre la Institucionalización de una Comunidad Académica.

3. Golob, S.R. Evolution or Revolution? Transitional Justice Culture Across Borders.

4. Arias Aparicio, F. Organización y Producción del Conocimiento Científico en los Organismos Públicos de Investigación Agraria: El Instituto Nacional de Investigación Agraria y Alimentaria (INIA).

5. Moreno, L. Welfare Mix, CSR and Social Citizenship.

6. Martínez, C. \& Rama, R. The control and generation of technology in European food and beverage multinationals.

7. Del Pino, E. \& Colino, C. National and Subnational Democracy in Spain: History, Models and Challenges.

8. Closa, C. Negotiating the Past: Claims for Recognition and Policies of Memory in the EU. 